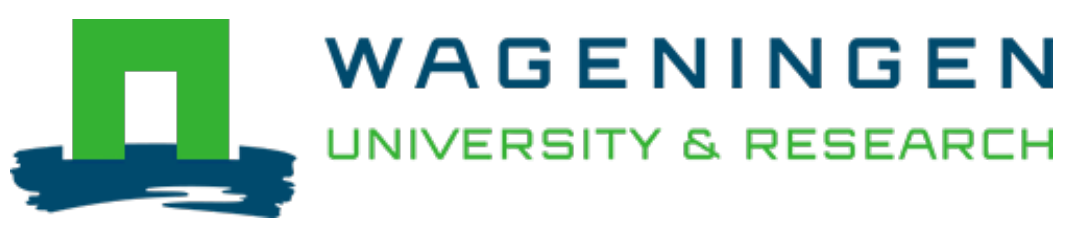

\title{
Methyl Chloroform Continues to Constrain the Hydroxyl (OH) Variability in the Troposphere
}

\author{
Journal of Geophysical Research: Atmospheres \\ Patra, P.K.; Krol, M.C.; Prinn, R.G.; Takigawa, M.; Mühle, J. et al \\ https://doi.org/10.1029/2020JD033862
}

This publication is made publicly available in the institutional repository of Wageningen University and Research, under the terms of article $25 \mathrm{fa}$ of the Dutch Copyright Act, also known as the Amendment Taverne. This has been done with explicit consent by the author.

Article 25 fa states that the author of a short scientific work funded either wholly or partially by Dutch public funds is entitled to make that work publicly available for no consideration following a reasonable period of time after the work was first published, provided that clear reference is made to the source of the first publication of the work.

This publication is distributed under The Association of Universities in the Netherlands (VSNU) 'Article $25 \mathrm{fa}$ implementation' project. In this project research outputs of researchers employed by Dutch Universities that comply with the legal requirements of Article $25 \mathrm{fa}$ of the Dutch Copyright Act are distributed online and free of cost or other barriers in institutional repositories. Research outputs are distributed six months after their first online publication in the original published version and with proper attribution to the source of the original publication.

You are permitted to download and use the publication for personal purposes. All rights remain with the author(s) and / or copyright owner(s) of this work. Any use of the publication or parts of it other than authorised under article $25 \mathrm{fa}$ of the Dutch Copyright act is prohibited. Wageningen University \& Research and the author(s) of this publication shall not be held responsible or liable for any damages resulting from your (re)use of this publication.

For questions regarding the public availability of this publication please contact openscience.library@wur.nl 


\section{JGR Atmospheres}

\section{RESEARCH ARTICLE \\ 10.1029/2020JD033862 \\ Methyl Chloroform Continues to Constrain the Hydroxyl $(\mathrm{OH})$ Variability in the Troposphere}

Key Points:

- High-quality measurements of $\mathrm{CH}_{3} \mathrm{CCl}_{3}$ from two independent measurement networks provide key information about tropospheric $\mathrm{OH}$ variability

- We separate effects of the "physical" climate on inverse lifetime of $\mathrm{CH}_{3} \mathrm{CCl}_{3}\left(K_{G}\right)$ from those arising from "chemical" changes in the atmosphere

- Robust variability in $K_{G}$, correlating with the El Niño Southern Oscillation, has large implications, e.g., for the global methane budget

Supporting Information:

- Supporting Information S1

Correspondence to:

P. K. Patra and M. C. Krol,

prabir@jamstec.go.jp;

Maarten.Krol@wur.n

Citation:

Patra, P. K., Krol, M. C., Prinn, R. G., Takigawa, M., Mühle, J., Montzka, S. A., et al. (2021). Methyl chloroform continues to constrain the hydroxyl $(\mathrm{OH})$ variability in the troposphere. Journal of Geophysical Research: Atmospheres, 126, e2020JD033862.

https://doi.org/10.1029/2020JD033862

Received 10 SEP 2020

Accepted 23 DEC 2020

Author Contributions:

Conceptualization: M. C. Krol, R. G. Prinn, M. Takigawa, S. A. Montzka, Y. Yamashita, J. W. Elkins

Data curation: J. Mühle, S. A

Montzka, S. Lal, R. F. Weiss, P. B.

Krummel, P. J. Fraser, S. O'Doherty, J. W. Elkins

Formal analysis: M. C. Krol, Naveen

Chandra, P. B. Krummel

Investigation: M. C. Krol, R. G. Prinn, P. J. Fraser

Methodology: R. G. Prinn, M

Takigawa, J. Mühle, Y. Yamashita, Stijn Naus

Resources: R. F. Weiss, P. J. Fraser, J. W. Elkins

(C) 2020. American Geophysical Union. All Rights Reserved.

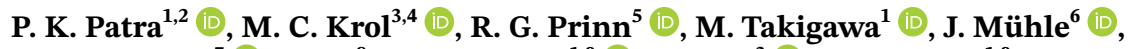

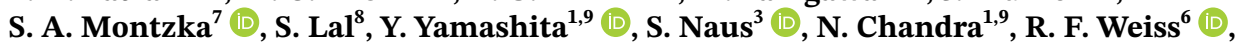 \\ P. B. Krummel ${ }^{10}$ D, P. J. Fraser ${ }^{10}$, S. O'Doherty ${ }^{11}$ iD, and J. W. Elkins ${ }^{7}$
}

${ }^{1}$ Research Institute for Global Change, Japan Agency for Marine-Earth Sciences and Tech. (JAMSTEC), Yokohama, Japan, ${ }^{2}$ Center for Environmental Remote Sensing, Chiba University, Chiba, Japan, ${ }^{3}$ Meteorology and Air Quality Group, Wageningen University, Wageningen, The Netherlands, ${ }^{4}$ Institute for Marine and Atmospheric Research Utrecht, Utrecht University, Utrecht, The Netherlands, ${ }^{5}$ Massachusetts Institute of Technology, Cambridge, MA, USA, ${ }^{6}$ Scripps Institution of Oceanography, University of California, San Diego, CA, USA, ${ }^{7}$ NOAA Global Monitoring Laboratory, Boulder, CO, USA, ${ }^{8}$ Physical Research Laboratory, Ahmedabad, Gujarat, India, ${ }^{9}$ Now at National Institute for Environmental Studies, Tsukuba, Japan, ${ }^{10}$ Climate Science Centre, CSIRO Oceans and Atmosphere, Aspendale, VIC, Australia, ${ }^{11}$ School of Chemistry, University of Bristol, Bristol, UK

Abstract Trends and variability in tropospheric hydroxyl $(\mathrm{OH})$ radicals influence budgets of many greenhouse gases, air pollutant species, and ozone depleting substances. Estimations of tropospheric $\mathrm{OH}$ trends and variability based on budget analysis of methyl chloroform $\left(\mathrm{CH}_{3} \mathrm{CCl}_{3}\right)$ and processbased chemistry transport models often produce conflicting results. Here we use a previously tested transport model to simulate atmospheric $\mathrm{CH}_{3} \mathrm{CCl}_{3}$ for the period 1985-2018. Based on mismatches between model output and observations, we derive consistent anomalies in the inverse lifetime of $\mathrm{CH}_{3} \mathrm{CCl}_{3}\left(K_{G}\right)$ using measurements from two independent observational networks (National Oceanic and Atmospheric Administration and Advanced Global Atmospheric Gases Experiment). Our method allows a separation between "physical" (transport, temperature) and "chemical" (i.e., abundance) influences on $\mathrm{OH}+\mathrm{CH}_{3} \mathrm{CCl}_{3}$ reaction rate in the atmosphere. Small increases in $K_{G}$ due to "physical" influences are mostly driven by increases in the temperature-dependent reaction between $\mathrm{OH}$ and $\mathrm{CH}_{3} \mathrm{CCl}_{3}$ and resulted in a smoothly varying increase of $0.80 \%$ decade $^{-1}$. Chemical effects on $K_{G}$, linked to global changes in $\mathrm{OH}$ sources and sinks, show larger year-to-year variations $(\sim 2 \%-3 \%)$, and have a negative correlation with the El Niño Southern Oscillation. A significant positive trend in $K_{G}$ can be derived after 2001, but it persists only through 2015 and only if we assume that $\mathrm{CH}_{3} \mathrm{CCl}_{3}$ emissions decayed more slowly over time than our best estimate suggests. If global $\mathrm{CH}_{3} \mathrm{CCl}_{3}$ emissions dropped below $3 \mathrm{Gg}_{\text {year }}{ }^{-1}$ after 2015 , recent $\mathrm{CH}_{3} \mathrm{CCl}_{3}$ measurements indicate that the 2015-2018 loss rate of $\mathrm{CH}_{3} \mathrm{CCl}_{3}$ due to reaction with $\mathrm{OH}$ is comparable to its value 2 decades ago.

\section{Introduction}

Hydroxyl radicals are primarily produced in the Earth's atmosphere through the reaction of water vapor $\left(\mathrm{H}_{2} \mathrm{O}\right)$ with an excited state oxygen atom $\left(\mathrm{O}^{1} \mathrm{D}\right) . \mathrm{O}^{1} \mathrm{D}$ is produced through the photodissociation of atmospheric ozone $\left(\mathrm{O}_{3}\right)$ by solar ultraviolet radiation (Seinfeld \& Pandis, 2006). Equally important is secondary $\mathrm{OH}$ production (recycling) in determining the availability of $\mathrm{OH}$ in the troposphere, involving many chemical reactions of organic and inorganic species (Lelieveld et al., 2002). The $\mathrm{OH}$ free radical is central to tropospheric air pollution chemistry and is responsible for removal of multiple greenhouse gases, ozone depleting substances, and air pollutants (Crutzen \& Zimmermann, 1991; Levy, 1971; Prather \& Spivakovsky, 1990; Singh et al., 1995). A precise knowledge of the global mean abundance, trend, and interannual variability of $\mathrm{OH}$ is needed to estimate source and sink budgets of greenhouse gases and ozone depleting substances, such as methane $\left(\mathrm{CH}_{4}\right)$, hydrogen containing halocarbons (e.g., methyl halides, hydrofluorocarbons (HFCs), hydrochlorofluorocarbons (HFCs)), and methyl chloroform $\left(\mathrm{CH}_{3} \mathrm{CCl}_{3}\right)$ (Krol \& Lelieveld, 2003; Lovelock, 1977; Makide \& Rowland, 1981; Montzka et al., 2011; Naik et al., 2013; Patra et al., 2011; Prinn et al., 1992, 2001, 2005). The current lack of understanding of the causes for the observed $\mathrm{CH}_{4}$ growth rate variability over recent decades has created further incentives for better estimation of $\mathrm{OH}$ trends and variability (Rigby et al., 2017; Turner et al., 2017; Zhao et al., 2019). 
Software: M. Takigawa, Naveen Chandra

Validation: Stijn Naus

Writing - original draft: M. C. Krol, R. G. Prinn, J. Mühle, S. A. Montzka Writing - review \& editing: S. Lal, P. B. Krummel, P. J. Fraser
Due to the strong reactivity of $\mathrm{OH}$ in the atmosphere within a given air parcel, it has a short lifetime, typically $\sim 1 \mathrm{~s}$, and observation-based (re)construction of spatial distribution and temporal trends have remained elusive. As a result, space-time variations of $\mathrm{OH}$ are estimated indirectly using tracers such as $\mathrm{CH}_{3} \mathrm{CCl}_{3}$ (Krol \& Lelieveld, 2003; Montzka, 2000; Montzka et al., 2011; Patra et al., 2014; Prinn et al., 1992, 2001, 2005), ${ }^{14} \mathrm{CO}$ (Brenninkmeijer et al., 1992; Krol et al., 2008), and, more recently, satellite-derived HCHO and isoprene (Wells et al., 2020; Wolfe et al., 2019). Alternatively, simulations with global chemistry transport models (CTMs) are used to estimate the mean abundance, trend, and variability in OH (Dalsøren et al., 2016; Murray et al., 2014; Naik et al., 2013; Stevenson et al., 2020; Voulgarakis et al., 2013; Zhao et al., 2019). However, due to the uncertainties in precursor emissions, for example, of volatile organic compounds and nitrogen oxides $\left(\mathrm{NO}_{\mathrm{X}}\right)$, and in modeled processes, it is difficult to accurately simulate $\mathrm{OH}$ (Gaubert et al., 2017; Lelieveld et al., 2018; Nguyen et al., 2020; Wolfe et al., 2019), and models often produce $\mathrm{OH}$ variabilities which are inconsistent with indirect estimations (He et al., 2020; Stevenson et al., 2020).

Due to the ambiguity of recent model studies that derived global $\mathrm{OH}$ variability and trends from $\mathrm{CH}_{3} \mathrm{CCl}_{3}$ (Naus et al., 2019; Rigby et al., 2017; Turner et al., 2017), a recent study (Nicely et al., 2020) states that "current observations are insufficient to unambiguously derive current trends in OH.” This corroborates earlier findings suggesting inconsistent phasing in $\mathrm{CH}_{3} \mathrm{CCl}_{3}$-derived $\mathrm{OH}$ variability from year-to-year using data from different measurement networks and also when compared to full CTMs (Holmes et al., 2013; McNorton et al., 2016). Despite these issues, however, these CTM studies also concluded that $\mathrm{CH}_{3} \mathrm{CCl}_{3}$-derived $\mathrm{OH}$ variations from the Advanced Global Atmospheric Gases Experiment (AGAGE) and National Oceanic and Atmospheric Administration (NOAA) networks provided useful insights into long-term atmospheric $\mathrm{CH}_{4}$ variations (Montzka et al., 2011; Rigby et al., 2017; Turner et al., 2017).

Most studies that used measured $\mathrm{CH}_{3} \mathrm{CCl}_{3}$ to derive global mean $\mathrm{OH}$ trends and variability were performed with simplified multibox models (Rigby et al., 2017; Turner et al., 2017). As discussed in detail in Naus et al. (2019), this might lead to systematic biases in $\mathrm{OH}$ trends and variability, as box model approaches of chemical tracer simulations do not account for the heterogeneity and variability in emissions, chemistry, and transport. Moreover, by using box-averaged observations, it is likely that information from the collected $\mathrm{CH}_{3} \mathrm{CCl}_{3}$ time series has not been utilized to its full potential for deriving information about OH. It is most appropriate to use three-dimensional CTMs to infer the time evolution of two-dimensional $\mathrm{OH}$ variations (Bousquet et al., 2005; Naus et al., 2020). In this study, we take an intermediate approach where a three-dimensional model is used for the forward simulations, and global mean $\mathrm{OH}$ trends and variabilities are estimated from site-specific model-observation differences.

We use simulations of $\mathrm{CH}_{3} \mathrm{CCl}_{3}$ by the JAMSTEC's Model for Interdisciplinary Research On Climate (MIROC, version 4.0) atmospheric chemistry-transport model (MIROC4-ACTM) (Patra et al., 2018). First, we infer interannual variability (IAV) and trends in $\mathrm{OH}$ from the observation-model differences of $\mathrm{CH}_{3} \mathrm{CCl}_{3}$ mole fractions for sites located far away from source regions (next Section, Materials and Methods), then we discuss the implications of our findings for understanding the $\mathrm{OH}$ variability of the whole troposphere (Section 3, Results and discussion), followed up by major conclusions (Section 4).

\section{Materials and Methods}

\subsection{MIROC4-ACTM}

The MIROC4-ACTM is run at T42 horizontal resolution (approximately 2.8 degrees in latitude and longitude grid spacing). The model adapted a hybrid $\sigma$-pressure vertical coordinate system that consists of 67 layers, which enables a fully resolved description of the stratosphere and mesosphere (Watanabe et al., 2008). To drive tracer transport in the ACTM, meteorological fields of turbulent diffusion, temperature, convection, and advection are generated by the MIROC4 general circulation model forced by monthly mean sea-surface temperature variations. To better represent synoptic transport, horizontal winds and temperature of the ACTM at the altitude range of $\sim 980-0.018 \mathrm{hPa}$ are nudged with Japan Meteorological Agency Reanalysis (JRA-55) data products (Kobayashi et al., 2015). The performance of interhemispheric exchange rate and stratospheric mixing time in MIROC4-ACTM has been tested using nonreactive gases, for example, sulfur hexafluoride $\left(\mathrm{SF}_{6}\right)$ in the troposphere and carbon dioxide $\left(\mathrm{CO}_{2}\right)$ in the stratosphere (Patra et al., 2018). The model-observation comparisons of intersite differences in $\mathrm{SF}_{6}$ (Supporting Information [S1], Figure S1) pro- 
(a)

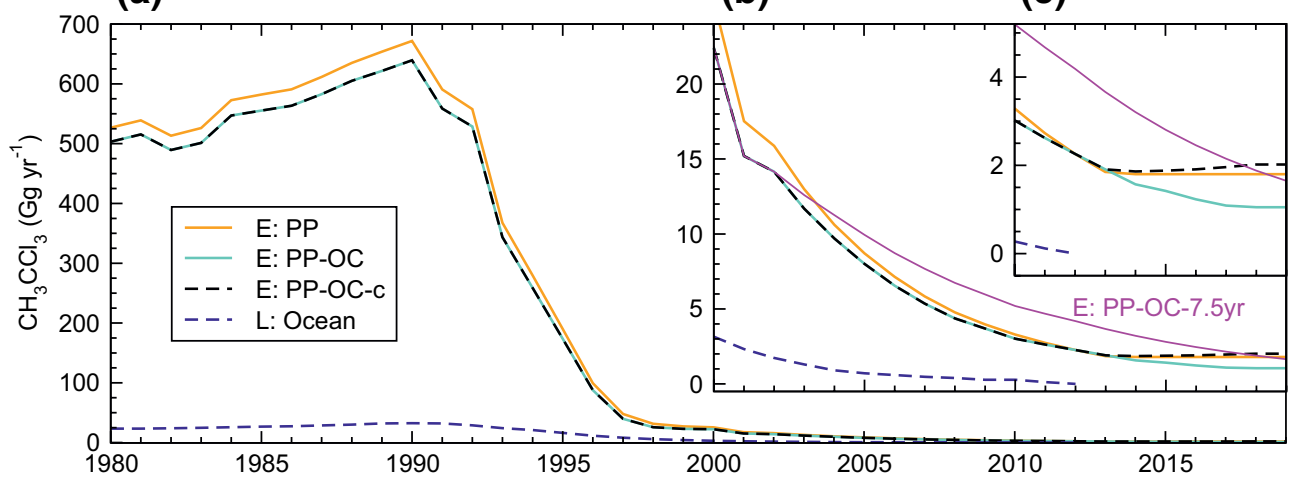

Figure 1. Time evolution of methyl chloroform $\left(\mathrm{CH}_{3} \mathrm{CCl}_{3}\right)$ net emission (E) scenarios used in MIROC4-ACTM simulations (a; see Table S1 for annual mean values). The atmosphere-ocean flux (L-loss to ocean) is also shown. The insets (b and c) show emissions from 2000 (b) and 2010 (c) onwards, respectively, with zoomed-in $y$-axis.

vide evidence that MIROC4-ACTM, nudged to the JRA-55, correctly represents features of interhemispheric and regional transport processes related to climate variations, including those related to El Niño Southern Oscillation (ENSO) (Francey et al., 2019; Patra et al., 2011). An accurate ENSO cycle is important in modeling $\mathrm{CH}_{3} \mathrm{CCl}_{3}$ observations (Prinn et al., 1992). Note that the JRA-55 meteorological fields are also used to calculate the multivariate ENSO index, version 2 (MEI.v2; www.esrl.noaa.gov/psd/enso/mei/) (Wolter \& Timlin, 2011).

To simulate mole fractions of $\mathrm{CH}_{3} \mathrm{CCl}_{3}$ at measurement locations during 1985-2018, the model uses offline $\mathrm{OH}$ fields and several emission scenarios as described below. All the model simulations are initiated at January 1, 1981, using an initial model field generated by a 20-year spin-up simulation (1981-2000). This spin-up period is used to set up proper concentration profiles in the stratosphere. The period 1981-1984 is considered as a secondary spin-up period to equilibrate $\mathrm{CH}_{3} \mathrm{CCl}_{3}$ sources and sinks with transport. Model simulations from 1985-2018 are used for our analysis.

\section{2. $\mathrm{CH}_{3} \mathrm{CCl}_{3}$ Emissions and Oceanic Sinks}

The time evolution of annual-mean emissions is based on industrial emission inventory information for 1980-2000 (McCulloch \& Midgley, 2001) and subsequent extrapolations to 2001-2019 as discussed below. No seasonality in the emissions is considered here. In contrast to previous 3D model simulations in which ocean loss was parametrized as a first order deposition process (Patra et al., 2011, 2014), we have now used the global total oceanic flux of $\mathrm{CH}_{3} \mathrm{CCl}_{3}$ for the period of 1980-2000 from Wennberg et al. (2004), albeit with the $\mathrm{CO}_{2}$ flux patterns in two sensitivity studies (PP-OC, PP-OC-c). These simulations account for the fact that $\mathrm{CH}_{3} \mathrm{CCl}_{3}$ that dissolved in the ocean during the 1980s and early 1990s may start to reenter the atmosphere on the net in the late 1990s, because the atmospheric $\mathrm{CH}_{3} \mathrm{CCl}_{3}$ abundance has dropped since 1998 at a faster rate than dissolved $\mathrm{CH}_{3} \mathrm{CCl}_{3}$. To account for the larger $\mathrm{CH}_{3} \mathrm{CCl}_{3}$ solubility in cold ocean water (Butler et al., 1991), we have spatially distributed the global total yearly sinks from that study using the $\mathrm{CO}_{2}$ flux pattern (Takahashi et al., 2009). The spatial distribution using proxy $\mathrm{CO}_{2}$ flux pattern is performed because the $\mathrm{CH}_{3} \mathrm{CCl}_{3}$ flux map data were not archived digitally from Wennberg et al. (2004) (Paul Wennberg, personal communication, June 2019). After 2000, we assume a linearly decreasing oceanic loss with zero deposition from 2012 onwards. The following emission scenarios are prepared for the simulation period 1981-2018 (Figure 1):

Case PP: Anthropogenic emissions are taken from Patra et al. (2014) for 1980-2013. After following reported industrial emissions (McCulloch \& Midgley, 2001), the emissions are extended for 2001-2013 with an exponential decay with a decay constant of 5 years. Emissions between 2014 and 2019 are kept constant.

Case PP-OC: As case PP, but with the ocean sink OC subtracted. Anthropogenic emissions between 2014 and 2019 continue to decrease in time. Oceanic sink is distributed using Takahashi et al. (2009) flux pattern. 
Case PP-OC-c: As PP-OC, but anthropogenic emissions between 2014 and 2019 increase slightly. Oceanic sink is distributed uniformly over all ocean grids. This will be used as our control case for this analysis. A mild increase in emissions over the recent 5 years is also suggested by joint $\mathrm{OH}$-emission inversion (Naus et al., 2020).

Case PP-OC-7.5 years: Same as PP-OC, but now the anthropogenic emissions are extended for 2001-2019 with an exponential decay with a decay constant of 7.5 years. This scenario is used to check the influence of the uncertainty in the emission drop after 2001 on the inferred $\mathrm{OH}$ trend.

The numerical values of anthropogenic emissions (with ocean uptake subtracted for Case PP-OC and PPOC-c) are given in the SI Table S1. The effects of oceanic sink and its patterns on $\mathrm{CH}_{3} \mathrm{CCl}_{3}$ simulations are shown in Figure S2 and discussed in Section 3.3. Figure 1 shows the time evolution of the globally integrated surface flux applied in the four scenarios.

\subsection{OH Fields and Chemical Reactions}

We use predefined tropospheric $\mathrm{OH}$ concentrations at monthly mean time intervals (Spivakovsky et al., 2000), after scaling the global totals by 0.92 to simulate global $\mathrm{CH}_{3} \mathrm{CCl}_{3}$ decay rates as in the TransCom$\mathrm{CH}_{4}$ experiment (Control OH, which has the NH/SH OH ratio of 0.99 [Patra et al., 2011], with the Northern and Southern Hemispheres [NH, SH] delineated at the equator). These predefined $\mathrm{OH}$ concentrations (Spivakovsky et al., 2000) were derived with a semi-empirical method to estimate seasonally varying $\mathrm{OH}$ fields using observed distributions of $\mathrm{O}_{3}, \mathrm{H}_{2} \mathrm{O}, \mathrm{NO}_{\mathrm{x}, \mathrm{tr}}$ (total reactive nitrogen oxides), $\mathrm{CO}$, hydrocarbons, temperature, and cloud optical depth. The $\mathrm{OH}$ field for the altitudes above $100 \mathrm{hPa}$ are taken from a CTM simulation of stratospheric ozone chemistry (Takigawa et al., 1999).

We have considered the following reactions to simulate $\mathrm{OH}$ chemistry and stratospheric photolysis $(\mathrm{J})$

$$
\begin{gathered}
\mathrm{CH}_{3} \mathrm{CCl}_{3}+\mathrm{OH} \rightarrow \text { products }\left[k_{\mathrm{OH}}=1.64 \times 10^{-12} \exp (-1520 / T)\right] \\
\mathrm{CH}_{3} \mathrm{CCl}_{3}+\mathrm{Cl} \rightarrow \text { products }\left[k_{\mathrm{Cl}}=3.0 \times 10^{-12} \exp (-1730 / T)\right] \\
\mathrm{CH}_{3} \mathrm{CCl}_{3}+\mathrm{J}(\mathrm{UV}) \rightarrow \text { products }
\end{gathered}
$$

with $k_{\mathrm{OH}}$ and $k_{\mathrm{Cl}}$ being the temperature dependent rate constant of $\mathrm{CH}_{3} \mathrm{CCl}_{3}$ with $\mathrm{OH}$ and $\mathrm{Cl}$, respectively (Burkholder et al., 2015). A climatological $\mathrm{Cl}$ field for the stratosphere at monthly time interval is taken from Takigawa et al. (1999). The photolysis rate $J$ is calculated online by parameterizing the ultraviolet (UV) absorption cross sections of $\mathrm{CH}_{3} \mathrm{CCl}_{3}$ from the database of Chemical Kinetics and Photochemical Data for Use in Atmospheric Studies (Burkholder et al., 2015).

\section{4. $\mathrm{CH}_{3} \mathrm{CCl}_{3}$ Measurements and Data Processing}

Measurements of $\mathrm{CH}_{3} \mathrm{CCl}_{3}$ are taken from five sites of the AGAGE (AGAGE; and its predecessors: the Atmospheric Lifetime Experiment, ALE, and the Global Atmospheric Gases Experiment, GAGE; Table 1) in situ monitoring network (Prinn et al., 2000, 2018). The gas chromatograph-multi detector (GC-MD) instruments use an electron capture detector (ECD) to make a calibrated air measurement of $\mathrm{CH}_{3} \mathrm{CCl}_{3}$ every $3 \mathrm{~h}$ (ALE), $2 \mathrm{~h}$ (GAGE), and $40 \mathrm{~min}$ (AGAGE), respectively. The "Medusa" instrument preconcentrates $2 \mathrm{~L}$ of air over 20 min with analysis by GC-MS (gas chromatography - mass spectrometry), leading to a calibrated ambient air measurement every 2 h (Arnold et al., 2012; Miller et al., 2008). All AGAGE measurements are reported on the SIO-05 gravimetric calibration scale. Additionally, we use discrete measurements from flasks collected by the NOAA halocarbon and other trace species (HATS) flask sampling network at 12 locations (Table 1) (Montzka et al., 2011). All HATS flask air samples are analyzed with a single GC-MS system at the NOAA laboratory in Boulder and the measurements for all sites are calibrated with respect to the same reference standard scale.

We use balloon-borne cryo-sampling observations from Hyderabad, India (Lal et al., 1994), and an observational data product from Gap, France (Fabian et al., 1996) for evaluation of the model simulated 
Table 1

List of AGAGE and NOAA Measurement Sites Used in This analysis, Along With Their Locations, Sampling Altitudes, and Periods of Operation

\begin{tabular}{|c|c|c|c|c|c|c|}
\hline Sl no. & Site name & Latitude & Longitude & Altitude, $\mathrm{m}$ asl $(\mathrm{agl})^{\mathrm{a}}$ & Data provider & Start of record \\
\hline 1 & Mace Head (MHD) & 53.33 & -9.9 & 25 & AGAGE & $1978-$ \\
\hline 2 & Trinidad Head (THD) & 41.05 & -124.15 & 140 & AGAGE & $1980-$ \\
\hline 3 & Barbados (RPB) & 13.17 & -59.43 & 42 & AGAGE & $1978-$ \\
\hline 4 & Samoa (SMO) & -14.23 & -170.57 & 77 & AGAGE & $1978-$ \\
\hline 5 & Cape Grim (CGO) & -40.68 & 144.68 & $164(70)$ & AGAGE & 1978- \\
\hline 1 & Alert (ALT) & 82.45 & -62.52 & 210 & NOAA & 1992- \\
\hline 2 & Pt. Barrow (BRW) & 73.32 & -156.6 & 8 & NOAA & 1992- \\
\hline 3 & Summit (SUM) & 72.58 & -38.48 & 3,200 & NOAA & 2004- \\
\hline 4 & Wisconsin (LEF) & 45.93 & -90.27 & $868(396)$ & NOAA & 1996- \\
\hline 5 & THD & 41.05 & -124.15 & 120 & NOAA & $2002-$ \\
\hline 6 & Niwot Ridge (NWR) & 40.03 & -105.57 & 3,475 & NOAA & 1992- \\
\hline 7 & Mauna Loa (MLO) & 19.54 & -155.58 & 3,397 & NOAA & 1992- \\
\hline 8 & Kumukahi (KUM) & 19.52 & -154.82 & 3 & NOAA & 1996- \\
\hline 9 & SMO & -14.23 & -170.57 & 77 & NOAA & 1992- \\
\hline 10 & CGO & -40.68 & 144.68 & $164(70)$ & NOAA & 1992- \\
\hline 11 & Palmer station (PSA) & -64.77 & -64.05 & 10 & NOAA & 1997- \\
\hline 12 & South Pole (SPO) & -89.99 & -24.8 & 2,837 & NOAA & 1992- \\
\hline Not used ${ }^{b}$ & Harvard forest (HFM) & - & - & - & NOAA & 1995- \\
\hline Not used $^{\mathrm{b}}$ & MHD & - & - & - & NOAA & 1998- \\
\hline
\end{tabular}

Abbreviations: AGAGE, Advanced Global Atmospheric Gases Experiment; NOAA, National Oceanic and Atmospheric Administration.

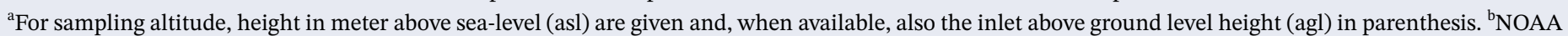

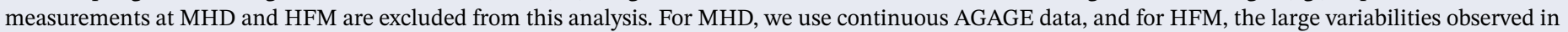
$\mathrm{CH}_{3} \mathrm{CCl}_{3}$ are poorly simulated by ACTM, especially in the early period with high emissions.

photo-chemical loss and transport of $\mathrm{CH}_{3} \mathrm{CCl}_{3}$ in the stratosphere. The balloon-borne measurements cover the altitude range of upper troposphere $(\sim 8 \mathrm{~km}$ in the mid-high latitudes and $\sim 10 \mathrm{~km}$ in the tropics $)$ up to the stratosphere (up to $\sim 35 \mathrm{~km}$ ). We also use $\mathrm{CH}_{3} \mathrm{CCl}_{3}$ observations from the National Aeronautics and Space Administration (NASA) operated high-altitude, atmospheric-sensing platforms on ER-2 aircrafts. During 1994-2000, NASA conducted several aircraft campaigns to probe the ozone hole formation and recovery by improving our understanding of chemistry, dynamics, and radiation in the upper troposphere and lower stratosphere (UT/LS) region. The measurements of $\mathrm{CH}_{3} \mathrm{CCl}_{3}$ are conducted by NOAA using the four-channel Airborne Chromatograph for Atmospheric Trace Species (ACATS-IV) during the Antarctic Southern Hemisphere Ozone Experiment (ASHOE), the Stratospheric Tracers of Atmospheric Transport (STRAT), the Photochemistry of Ozone Loss in the Arctic Region In Summer (POLARIS) and the SAGE III Ozone Loss and Validation Experiment (SOLVE) (Elkins et al., 1996; Romashkin et al., 2001).

The model simulations are sampled at the nearest model grid for each measurement location (Table 1) within half-an-hour of the actual sampling time. From the observations and the cosampled model values, we calculated monthly and annual-means that are used in the analysis. Both the measurements and model simulations are expressed in units of dry air mole fraction ( $\mathrm{pmol} \mathrm{mol}^{-1}$; parts-per-trillion, ppt).

\subsection{Indirect Estimation of Tropospheric $\mathrm{OH}$}

We have indirectly inferred mean tropospheric $\mathrm{OH}$ anomalies from the $\mathrm{CH}_{3} \mathrm{CCl}_{3}$ model-observation differences. As will be shown, the model simulations account for the main drivers (emissions, transport, sinks) of the observed $\mathrm{CH}_{3} \mathrm{CCl}_{3}$ time series. Note also that about $10 \%$ of $\mathrm{CH}_{3} \mathrm{CCl}_{3}$ is lost in the stratosphere, which is assumed to be modeled well (details in Section 3.2). Remaining model-observation differences are assumed 
to be caused by either inaccuracy in the applied emissions or by variations in $\mathrm{OH}$. To test the latter, we start from the budget equation of the global $\mathrm{CH}_{3} \mathrm{CCl}_{3}$ burden and its time variation:

$$
\frac{d B}{d t}=E-\frac{B}{\tau}
$$

where $B$ is the burden, $E$ are the emissions, and $\tau$ is the total lifetime of $\mathrm{CH}_{3} \mathrm{CCl}_{3}(\tau=1 /$ $\left(k_{\mathrm{OH}} \times[\mathrm{OH}]+k_{\mathrm{Cl}} \times[\mathrm{Cl}]+J\right)$. Throughout this study, we use observations and model results at monthly mean time intervals for the calculations. Knowing $\mathrm{CH}_{3} \mathrm{CCl}_{3}$ emissions, burden, and the burden change in time, we can derive the inverse tropospheric lifetime of $\mathrm{CH}_{3} \mathrm{CCl}_{3}$ toward loss by $\mathrm{OH}$ ( $K_{G}$, given the assumption that other loss frequencies remain constant over time), which is proportional global tropospheric mean OH (Montzka et al., 2011),

$$
K_{G}=\frac{1}{\tau}=\frac{E}{B}-\frac{\frac{d B}{d t}}{B}
$$

Note that modeled $K_{G}$ values, even with constant $\mathrm{OH}$ concentrations, may vary in time due to "physical" climate variations, associated with variations in transport and atmospheric temperature, and include the losses in the stratosphere by reaction with $\mathrm{Cl}$ radicals and photolysis. The physical $K_{G}$ variability $(=1 / \tau)$ can be calculated from the 3-D model simulation in which $[\mathrm{OH}],[\mathrm{Cl}]$, and photolysis are held constant from year-to-year. To separate this variability from variations caused by "chemical" factors such as variations in the $\mathrm{OH}$ abundance driven by its chemical sources and sinks, or wrongly represented $\mathrm{CH}_{3} \mathrm{CCl}_{3}$ emissions, we estimate anomalies in $K_{G}$. To this end, we compare modeled time series to observations at individual time stations. Given observations and model estimates of $B$ and $d B / d t$, anomalies in $K_{G}$ are defined as:

$$
\left.\left.\Delta K_{G}=\mathrm{E}\left[\frac{1}{B_{\mathrm{obs}}}-\frac{1}{B_{\mathrm{mod}}}\right]-\left[\llbracket \frac{\frac{d B_{\mathrm{obs}}}{d t}}{B_{\mathrm{obs}}}\right)-\llbracket \frac{\frac{d B_{\mathrm{mod}}}{d t}}{B_{\mathrm{mod}}}\right)\right]
$$

Here the subscripts "obs" and "mod" refer to observations and the model-based parameters, respectively. Alternatively, we may derive emission anomalies as:

$$
\Delta E=\frac{d\left[B_{\mathrm{obs}}-B_{\mathrm{mod}}\right]}{d t}+\frac{\left[B_{\mathrm{obs}}-B_{\mathrm{mod}}\right]}{\tau}
$$

To relate modeled and observed mole fractions (in ppt) to global burdens ( $B$, in $\mathrm{Gg}$ ), we use a factor of $23.65 \pm 0.07 \mathrm{Gg} \mathrm{ppt}^{-1}$ (mean and $1-\sigma$ standard deviation during 1985-2018). This factor represents the 1981-2018 mean (and 1- $\sigma$ standard deviation) of the yearly averaged modeled global $\mathrm{CH}_{3} \mathrm{CCl}_{3}$ burden over the modeled global mean mole fraction (mass-weighted). We have calculated $K_{G}$ anomalies separately for measurements from each of the AGAGE and NOAA sites before calculating the averages and 1- $\sigma$ standard deviations for a set of sites. In contrast to box model studies, this approach accounts for spatially resolved emissions and loss processes, as well as for interannually varying transport.

To further investigate drivers of physical $K_{G}$ variability (Section 3.3), we have performed additional MIROC4-ACTM simulations. In these simulations, we sequentially fix various drivers of variability: MCF emission, transport, and temperature. We fix the emissions to the year 1984 and temperature and transport to climate-driver data for the year 2010. The simulation with 1984 emissions and 2010 transport and temperature is expected to show negligible "physical" $K_{G}$ variability, since only interannually varying sea-surface temperature is accounted for, which is "overruled" by nudging the simulation to 2010 transport and/or temperature.

\section{Results and Discussion}

\subsection{Global $\mathrm{CH}_{3} \mathrm{CCl}_{3}$ Distributions in the Simulations}

To illustrate the changes in global $\mathrm{CH}_{3} \mathrm{CCl}_{3}$, Figure 2 shows the January and July latitude-pressure distribution simulated for two specific years: (1) 1990, when the global total emissions were at their peak 
(a) $\mathrm{CH}_{3} \mathrm{CCl}_{3}$, Jan 1990, 0-360E

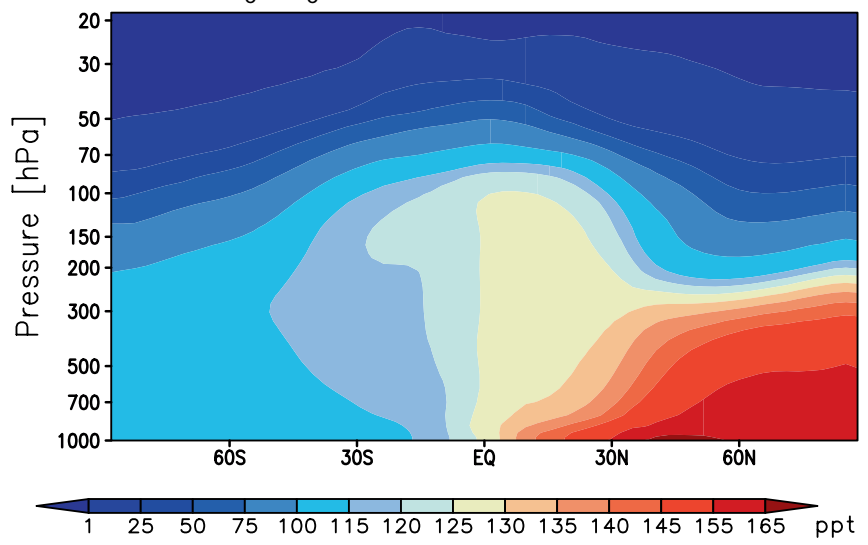

(c) $\mathrm{CH}_{3} \mathrm{CCl}_{3}$, Jan $2005,0-360 \mathrm{E}$

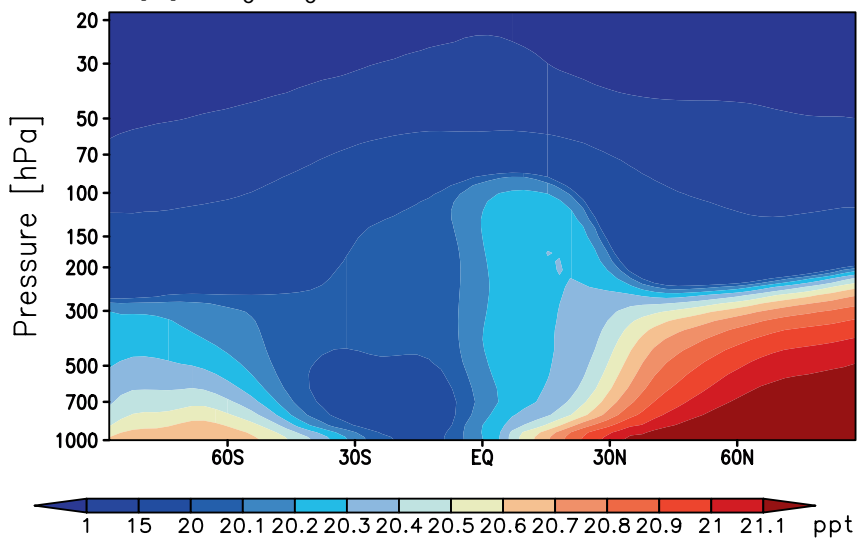

(b) $\mathrm{CH}_{3} \mathrm{CCl}_{3}, \mathrm{Jul} 1990,0-360 \mathrm{E}$

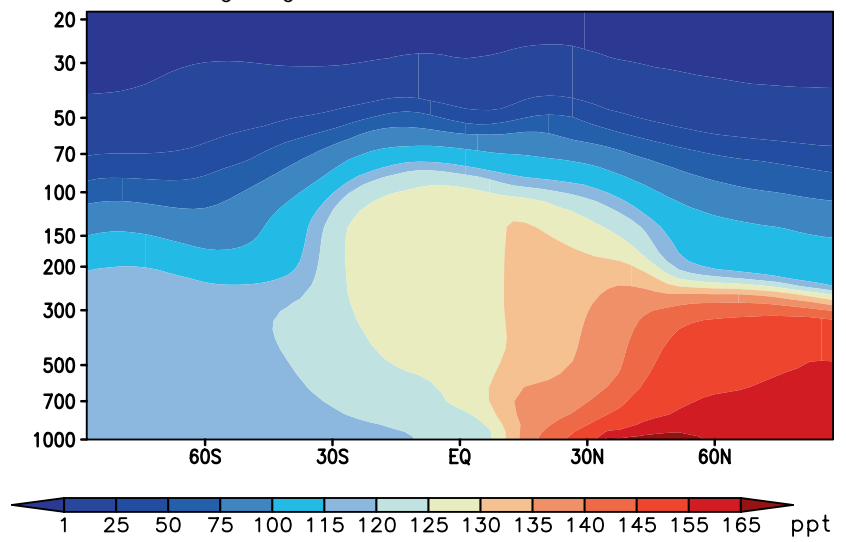

(d) $\mathrm{CH}_{3} \mathrm{CCl}_{3}, \mathrm{Jul} 2005,0-360 \mathrm{E}$

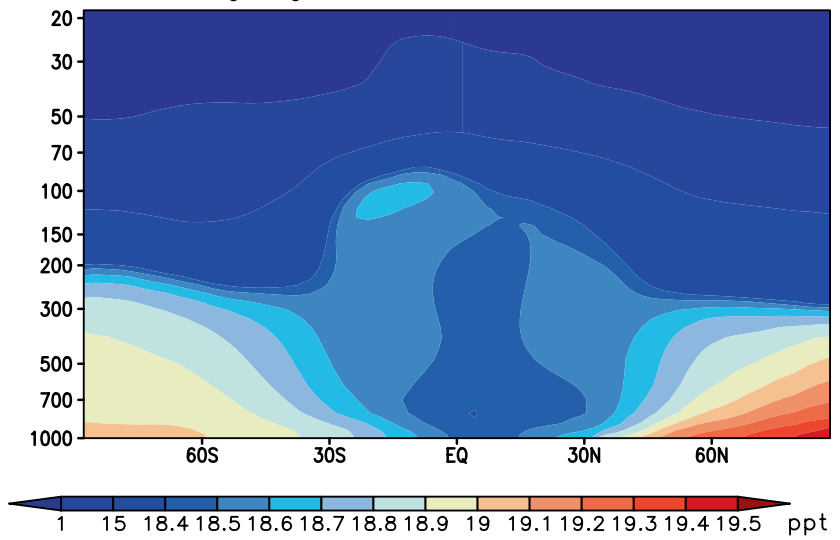

Figure 2. Latitude-pressure distribution of zonal mean $\mathrm{CH}_{3} \mathrm{CCl}_{3}$ during $\mathrm{NH}$ winter (left column) and NH summer (right column) simulated by MIROC4ACTM for 1990 (top row) and 2005 (bottom row), respectively (simulation PP-OC-c). Note that different color scales are used due to the rapidly changing concentrations of $\mathrm{CH}_{3} \mathrm{CCl}_{3}$, that is, a common scale for January and July 2005 would not clearly depict the horizontal and vertical gradients in the troposphere.

$\left(\sim 650 \mathrm{Gg} \mathrm{year}^{-1}\right)$ and tropospheric mole fractions were everywhere larger than $100 \mathrm{ppt}$ (top row), and (2) 2005, when the emissions had reduced substantially $\left(\sim 25 \mathrm{Gg} \mathrm{year}^{-1}\right)$ and mole fractions had fallen below 25 ppt (bottom row). In the 1990s, the distribution was dominated by transport in the upper troposphere from the $\mathrm{NH}$, where emissions dominate, toward the $\mathrm{SH}$. The tropical transport barrier due to the intertropical convergence zone (ITCZ) is stronger in January and weakens due to the South Asian monsoon in July (Figures $2 \mathrm{a}$ and $2 \mathrm{~b}$ ). The situation changed dramatically by 2005 (Figures $2 \mathrm{c}$ and $2 \mathrm{~d}$ ), when emissions had become a small term in the global $\mathrm{CH}_{3} \mathrm{CCl}_{3}$ mass balance equation (Equation 1) (Montzka et al., 2011). By that time, removal by $\mathrm{OH}$ in the tropical troposphere had become the dominant term in the global $\mathrm{CH}_{3} \mathrm{CCl}_{3}$ budget. Removal by $\mathrm{OH}$ is evident from the local minimum that is simulated in the tropics, which migrates seasonally from the $\mathrm{SH}$ to the $\mathrm{NH}$ following the maximum in solar intensity (Figures $2 \mathrm{c}$ and $2 \mathrm{~d}$ ). Based on the calculations in MIROC4-ACTM, the local lifetime of $\mathrm{CH}_{3} \mathrm{CCl}_{3}$ varies from about 3 months in the tropical lower troposphere to 7 years in the tropical upper troposphere $(\sim 200 \mathrm{mb})$ and at $60^{\circ}$ latitude near the Earth's surface in the model.

\subsection{Evaluation of $\mathrm{CH}_{3} \mathrm{CCl}_{3}$ Simulation in the Upper Troposphere and Stratosphere}

About $10 \%$ of $\mathrm{CH}_{3} \mathrm{CCl}_{3}$ is lost to the stratosphere, and the loss budget of $\mathrm{CH}_{3} \mathrm{CCl}_{3}$ toward the stratosphere primarily depends on stratosphere-troposphere exchange. To validate the ability of the model to simulate the vertical gradient of $\mathrm{CH}_{3} \mathrm{CCl}_{3}$ in the stratosphere, Figure 3 shows the comparisons of observed and simulated $\mathrm{CH}_{3} \mathrm{CCl}_{3}$ vertical profiles in the stratosphere. Uncalibrated observations from Hyderabad, India $\left(17.5^{\circ} \mathrm{N}, 78.6^{\circ} \mathrm{E}\right)$ in March 1990 are scaled by 0.787 to match the simulated concentration, averaged over 
(a)

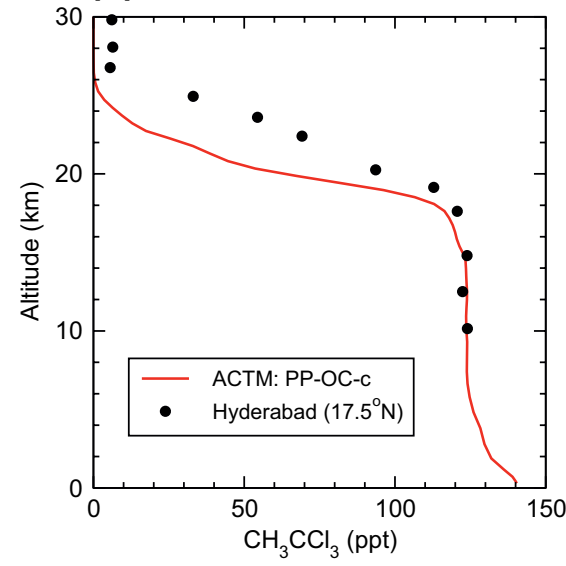

(b)

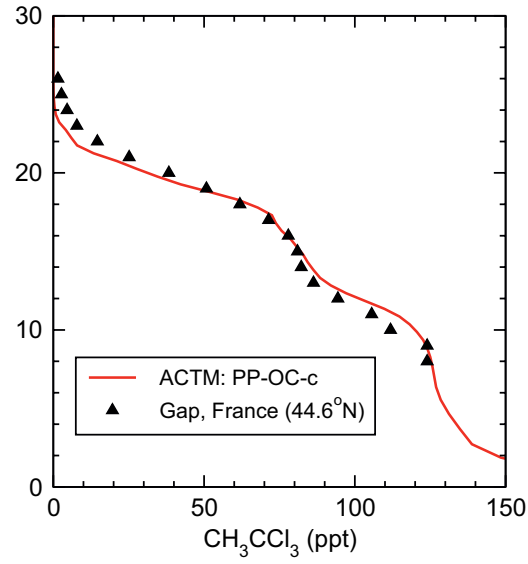

Figure 3. Comparisons of MIROC4-ACTM simulated $\mathrm{CH}_{3} \mathrm{CCl}_{3}$ vertical profiles with those (a) observed at Hyderabad, India in March 1990 (Lal et al., 1994) (Table S2) and (b) constructed for Gap, France in June 1987 (Fabian et al., 1996) (Table S2). The values from the two sites are scaled to model values in the troposphere, because the aim of this analysis is to validate $\mathrm{CH}_{3} \mathrm{CCl}_{3}$ vertical gradients in the stratosphere.

March 1990, at $10 \mathrm{~km}$ which represents tropospheric air (Lal et al., 1994). Similarly, the reference $\mathrm{CH}_{3} \mathrm{CCl}_{3}$ profile from Gap, France $\left(44.6^{\circ} \mathrm{N}, 6.1^{\circ} \mathrm{E}\right)$, representative of June 1987 , is also scaled by 0.855 to match the simulated tropospheric concentration at $8 \mathrm{~km}$ (Fabian et al., 1996). The simulated concentrations for Hyderabad match with the observed value of $112 \mathrm{ppt}$ within $13 \%$ at $19 \mathrm{~km}$ (lower stratosphere). The tropopause height was observed at $16.5 \mathrm{~km}$ during the balloon flight. The observed and simulated profiles match better below $19 \mathrm{~km}$ (within 4\%), and major difference are seen in the altitude range 20-25 km (Figure 3a). Good agreement is also seen for the altitude (26-27 km) at which $\mathrm{CH}_{3} \mathrm{CCl}_{3}$ observations hit the detection limit and simulated concentrations diminish. The observation-based reference profile and simulation show excellent agreement at all heights over Gap, France (Figure 3b).

To further evaluate the model simulations in the upper troposphere and stratosphere region, we have compared the simulated concentrations along the flight tracks of 4 NASA aircraft campaigns from 1994 to 2000 (Figure 4). Figure 4a shows that the model simulated concentrations closely follow the concentration changes at different latitude and heights (low values correspond to the stratosphere, mostly at around 18-20 km, and high values correspond to the middle and upper troposphere of 5-10 or $15 \mathrm{~km}$, depending on the latitude). Quite a few of the ASHOE flights and all of the STRAT flights were operated in the tropical latitudes, and thus $\mathrm{CH}_{3} \mathrm{CCl}_{3}$ concentrations typical of the troposphere are measured up to $\sim 16 \mathrm{~km}$. For the POLARIS and SOLVE flights, concentrations started to decrease significantly above $\sim 10 \mathrm{~km}$ (Figure $4 \mathrm{c}$ ). Figure $4 \mathrm{~b}$ showed good agreement between the model and observed $\mathrm{CH}_{3} \mathrm{CCl}_{3}$ for each flight (correlation coefficients, $r$, greater than 0.93 ).

Based on the comparisons of the model simulations using balloon and aircraft observations, we conclude that stratospheric-tropospheric exchange and the loss of $\mathrm{CH}_{3} \mathrm{CCl}_{3}$ in the stratosphere is realistically modeled in ACTM, and proceed with analyzing the tropospheric $\mathrm{CH}_{3} \mathrm{CCl}_{3}$ budget and the impact of tropospheric $\mathrm{OH}$ on this budget.

\subsection{Time Evolution of $\mathrm{CH}_{3} \mathrm{CCl}_{3}$ mole Fractions, Lifetime, and Derived $\mathrm{OH}$ Variability}

Figure 5 shows that the MIROC4-ACTM simulations, with constant $\mathrm{OH}$, reproduce the $\mathrm{CH}_{3} \mathrm{CCl}_{3}$ mole fractions at Cape Grim (CGO; $41^{\circ} \mathrm{S}, 145^{\circ} \mathrm{E}$ ) well within $10 \%$ (results for the other AGAGE stations are presented in Figure S3). The best agreement is obtained with simulation PP-OC-c (Figure 5b), in which the ocean sink is included and post-2014 emissions are almost constant. We suggest that the inclusion of the oceanic sink, calculated in an earth-system model (Wennberg et al., 2004), is responsible for the improvements compared to our earlier modeling studies (Patra et al., 2014). These improvements are evident from the systematically smaller model-observation differences during 1985-2005 in the simulations that include the ocean sink 
(a)

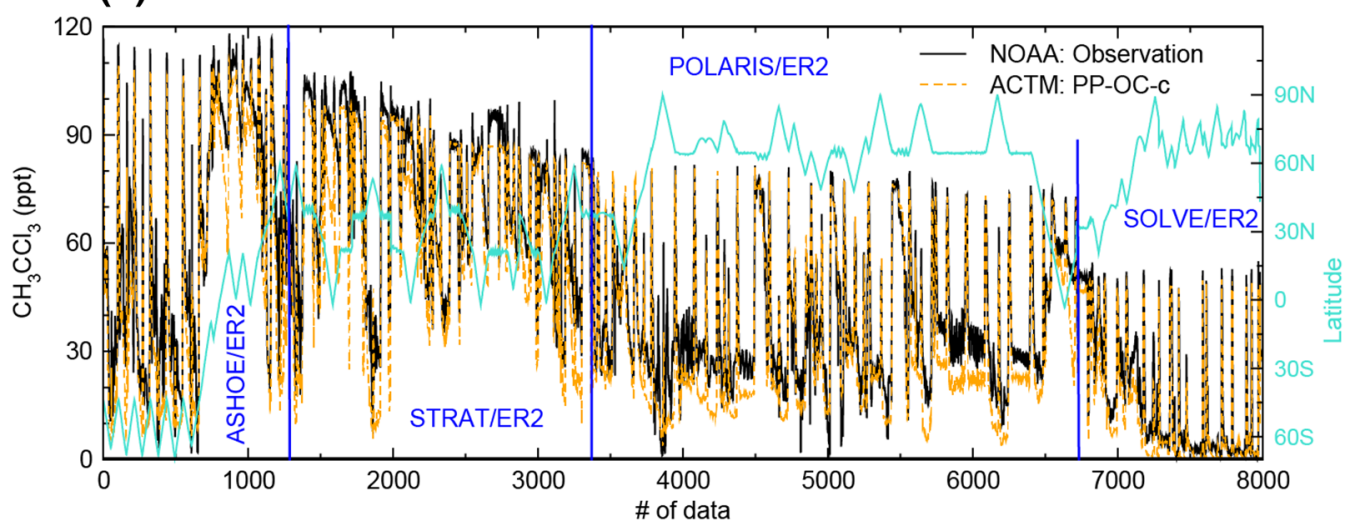

(b)

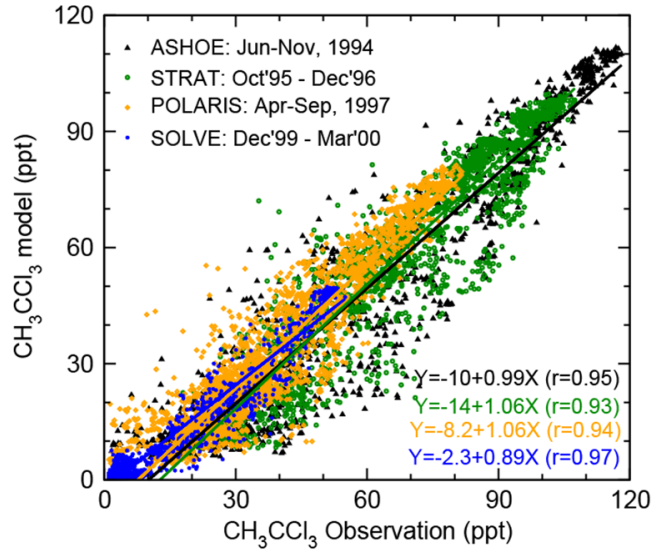

(c)

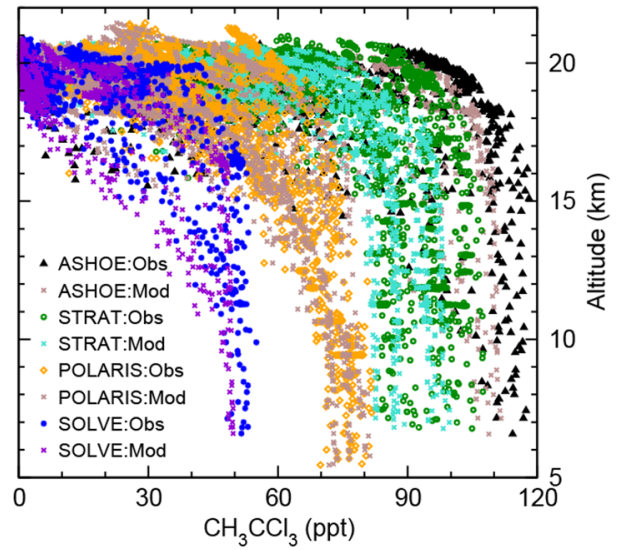

Figure 4. Comparisons of $\mathrm{CH}_{3} \mathrm{CCl}_{3}$ measurements and model in the UT/LS region. Measurements by NOAA were made by the ACATS-IV instrument onboard ER-2 aircraft campaigns (ASHOE, STRAT, POLARIS, and SOLVE). Panel (a) (top) shows the data for all four campaigns and latitude of flight operation. Panel (b) (bottom-left) shows the statistical significance of the model-observation agreements. Panel (c) (bottom-right) shows the vertical distributions of $\mathrm{CH}_{3} \mathrm{CCl}_{3}$ as observed and modeled. ACATS-IV, Airborne Chromatograph for Atmospheric Trace Species; ASHOE, Antarctic Southern Hemisphere Ozone Experiment; NOAA, National Oceanic and Atmospheric Administration; POLARIS, Photochemistry of Ozone Loss in the Arctic Region In Summer; SOLVE, SAGE III Ozone Loss and Validation Experiment; STRAT, Stratospheric Tracers of Atmospheric Transport.

(PP-OC cases). In other words, if the oceanic sink is neglected, we would need systematically greater $\mathrm{OH}$ (or lower $\mathrm{CH}_{3} \mathrm{CCl}_{3}$ emissions) in the second half of the 1980s and that the $\mathrm{OH}$ had to decrease until about the middle of the 1990s, also evident in an earlier study (Bousquet et al., 2005).

The exact decline of the emissions since 2001, however, remains uncertain because no inventory-based emission estimates are available. The overall tendency of simulations to underestimate observed mole fractions after 2015 points to underestimated emissions (Rigby et al., 2017). We therefore test the impact of a slower decline in emissions after 2001 with the PP-OC-7.5 years emission scenario, which results in a positive model-observation differences in $\mathrm{CH}_{3} \mathrm{CCl}_{3}$ after 2010 (Figure 5b) and a persistent positive $K_{G}$ anomaly for 2010-2014.

As argued above, the modeled $K_{G}$ may vary in time due to "physical" climate variations, associated with variations in transport and atmospheric temperature, or due to "chemical factors" such as changes in $\mathrm{OH}$ or wrongly represented $\mathrm{CH}_{3} \mathrm{CCl}_{3}$ emissions. To separate the "physical" and "chemical" variability, we estimate anomalies in $K_{G}$. When the model-observation differences at CGO are projected on global $K_{G}$ anomalies (Equation 3, Figure 5c), values range within $\pm 8 \%$ (1998-2018 standard deviation of annual means in Figure 5c amounts to 3.7\%) of the mean $K_{G}$ of 0.198 year ${ }^{-1}$ (equivalent to mean $\mathrm{CH}_{3} \mathrm{CCl}_{3}$ lifetime of $5.05 \pm 0.10$ years) for the control emission case (PP-OC-c). Note that the PP-OC-7.5 years scenario with 

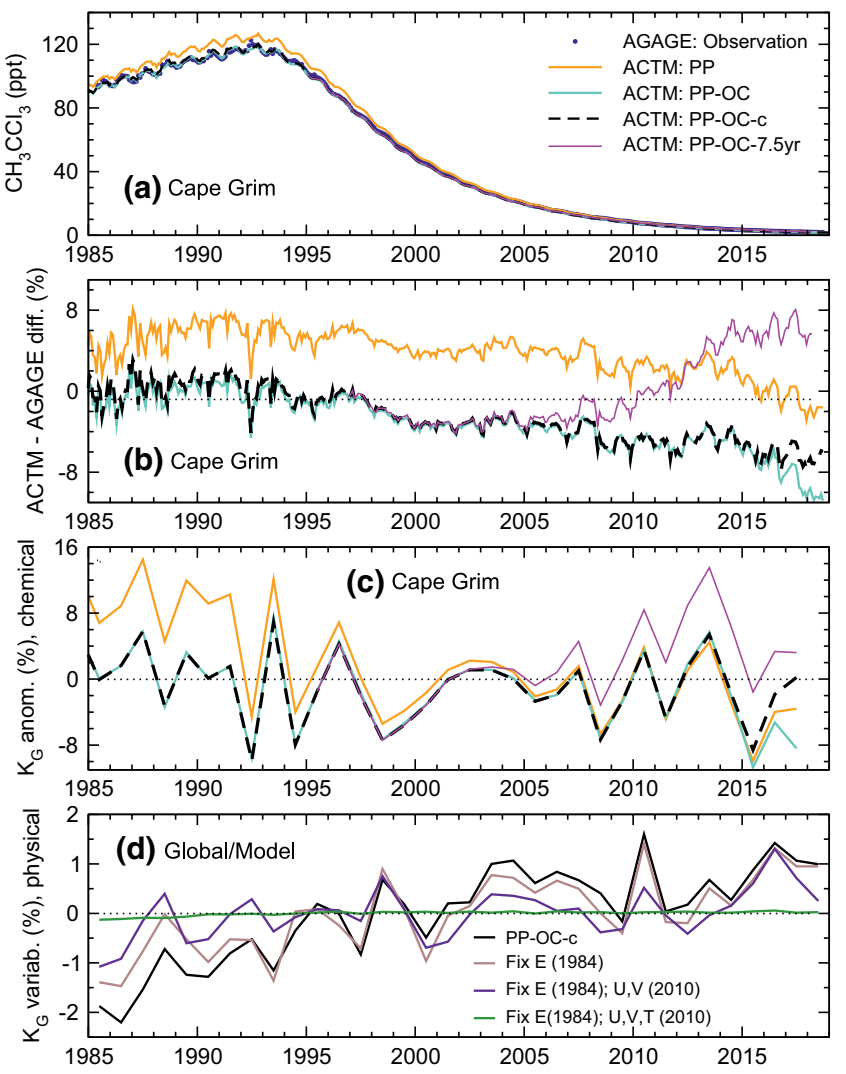

Figure 5. (a) Time series of monthly mean simulated mole fractions and AGAGE observations of $\mathrm{CH}_{3} \mathrm{CCl}_{3}$ for the period 1981-2018 at Cape Grim Observatory (CGO; $\left.41^{\circ} \mathrm{S}, 145^{\circ} \mathrm{E}\right)$. Panel (b) shows the monthly modelobservation differences at CGO, and in panel (c), the inferred yearly "chemical" $K_{G}$ anomalies using CGO data are shown. Panel (d) presents the "physical" model-calculated $K_{G}$ variations (Equation 2) in black. The brown, purple, and green lines are derived from simulations with respectively constant 1984 emissions, constant 1984 emissions (E) and climatological 2010 horizontal winds (U, V), and constant 1984 emissions (E) and climatological 2010 winds and temperature (U, V, T). AGAGE, Advanced Global Atmospheric Gases Experiment. higher emissions, leads to a positive deviation in the calculated $K_{G}$ anomalies (Figure 5c), but interannual variations remain robust. This indicates that emissions remain a critical factor in assessing $K_{G}$, and [OH], trends. Before 1998, uncertainties in emissions render the projection of model-observation mismatches on $K_{G}$ less reliable (Montzka et al., 2011). $K_{G}$ variations in the most recent years (2015 onwards) may also be less reliable, due to the small atmospheric $\mathrm{CH}_{3} \mathrm{CCl}_{3}$ burden, instrumental issues related to accurately measuring small atmospheric mole fractions, and uncertainty in remaining emissions.

The $K_{G}$ anomalies are superimposed on the MIROC4-ACTM's internal "physical" IAVs and trend, which shows a $\sim 3 \%$ increase in $K_{G}$ over the past $\sim 30$ years (black line in Figure $5 d$ ). This corresponds to a lifetime decrease from $5.11 \pm 0.10$ years during 1986-1996 to $4.95 \pm 0.10$ years during 2009-2018. Variations in annual mean $K_{G}$ in this simulation are on the order of $1 \%$, for instance during the El-Niño and La-Niña events around 1998 and 2010, respectively (the ENSO and $K_{G}$ variability is further addressed in Section 3.4). The systematic increase in physical $K_{G}$ $\left(0.80 \%\right.$ decade $^{-1}$ in the period $\left.1985-2018\right)$ is caused (1) by changes in the rate of stratosphere-troposphere exchange of $\mathrm{CH}_{3} \mathrm{CCl}_{3}$ due the modifications in latitude-height gradients with time (see Figure 2), (2) by increases in temperature-dependent loss rates, and (3) by trends in transport processes that bring $\mathrm{CH}_{3} \mathrm{CCl}_{3}$ to its main sink area in the tropics (Naus et al., 2019). The effect of the changing global $\mathrm{CH}_{3} \mathrm{CCl}_{3}$ distribution on $K_{G}$ is assessed by a simulation with constant 1984 emissions (Fix E case in Figure $5 \mathrm{~d}, 0.55 \%$ decade $^{-1}$ increase in $K_{G}$ ). This simulation results in a steady state $\mathrm{CH}_{3} \mathrm{CCl}_{3}$ distribution, with lifetime variations driven solely by temperature and transport variations. The effects of transport and temperature are assessed separately by nudging the winds (purple line, $0.035 \%$ decade $^{-1}$ increase in $K_{G}$ ) and winds and temperature (green line, $0.25 \%$ decade $^{-1}$ increase in $K_{G}$ ) repeatedly to meteorological driver data of 2010. This shows a dominant role for the temperature in driving both the trend and interannual variations of $K_{G}$.

We found that the model-observation $\mathrm{CH}_{3} \mathrm{CCl}_{3}$ differences produce highly consistent variations across all AGAGE stations (Figure S3), which points to a common global driver. As a test for the interannual transport simulated by MIROC4-ACTM, we compared the meridional gradients in sulfur hexafluoride $\left(\mathrm{SF}_{6}\right)$ measured at $\mathrm{CGO}$ and eight other sites located north of CGO measured by NOAA (Figure S1). The model and observed gradients show statistically significant correlation coefficients, 0.62 or greater for seven out of eight sites. Slightly lower correlation coefficients (0.38) for the Ascension Island (ASC)-CGO differences may arise from the coarse spatial resolution of the model (T42) or uncertainties in the emission distribution or precision of the measurement $(\sim 0.04 \mathrm{ppt}$ for the NOAA flask measurements). Because the other terms in the $\mathrm{CH}_{3} \mathrm{CCl}_{3}$ budget are not likely to exhibit strong interannual variations, it seems justified to assign these mismatches to "chemical" $K_{G}$ variations, caused by $\mathrm{OH}$ changes.

\subsection{Trends and Anomalies in Global Mean $\boldsymbol{K}_{G}$}

Figure 6 depicts the global monthly $K_{G}$ anomalies from the PP-OC-c scenario as derived by separately averaging $K_{G}$ data from either 5 AGAGE (Prinn et al., 2018) or 12 NOAA (Montzka et al., 2011) sites (Table 1). The corresponding emission anomalies derived using Equation 4 are presented in Figure S4. The NOAA and AGAGE monthly values represent the arithmetic mean of the individual stations' estimates, and co-vary in time with a Pearson's moment correlation coefficient of $r=0.31$ (Figure 6), suggesting a robust estimation of 


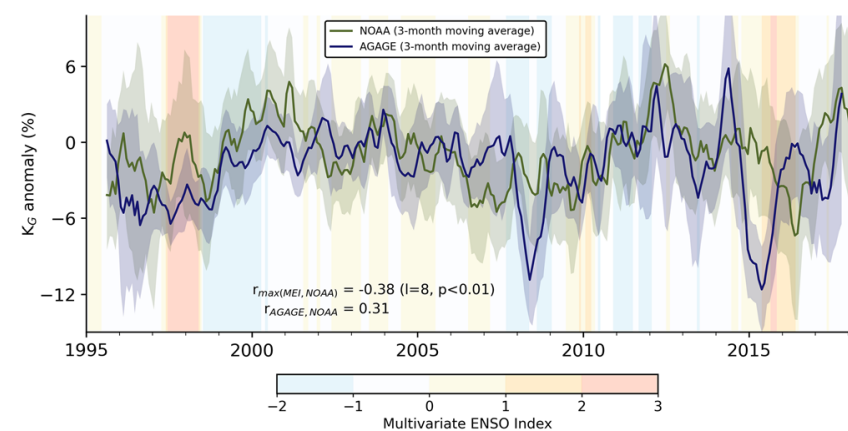

Figure 6. Time series of monthly $K_{G}$ anomalies, estimated by combining AGAGE and NOAA measurement sites, with $1-\sigma$ standard deviations shown by shading. The shaded bars in the background represent the multivariate ENSO index, version 2 (MEI.v2) (Wolter \& Timlin, 2011). AGAGE, Advanced Global Atmospheric Gases Experiment; ENSO, El Niño Southern Oscillation; NOAA, National Oceanic and Atmospheric Administration.
$K_{G}$ anomalies from these independent measurements. Larger differences between the networks in 2007-2008 and 2014-2015 are not well understood. Both networks agree on positive $K_{G}$ anomalies during 2000-2005 and around 2012, and on the absence of a significant long-term trend during 2000-2014 in the PP-OC-c emission scenario. A similar analysis but for $\mathrm{CH}_{3} \mathrm{CCl}_{3}$ decay rate anomaly was performed by Holmes et al. (2013), where they reported a systematic offset between the two networks during 19982001, a period when emissions are still significant for northern-southern hemisphere differences in $\mathrm{CH}_{3} \mathrm{CCl}_{3}$. We suspect their results are an artifact of not accounting for the differences in the observational network, which is minimized here by taking model-observation differences.

Since, $K_{G}$ is mainly proportional to global mean $\mathrm{OH}$ abundance, we compare our results of $K_{G}$ anomalies with $\mathrm{OH}$ anomalies from the published literature. The annual $K_{G}$ variability estimated here $(2.08 \%$ for NOAA and $2.67 \%$ for AGAGE during 1996-2015) is only slightly lower than the box-model estimates reported as $2.98 \%$ by Turner et al. (2017) and 3.04\% by Rigby et al. (2017), or $2.3 \%$ by Montzka et al. (2011) over a shorter period of 1998-2007. This is in line with our finding that "chemical" drivers (Figure 5c) dominate over "physical” drivers (Figure 5d) of $K_{G}$ variability at any given decade since 1985 .

The derived $K_{G}$ anomalies anticorrelate with ENSO (to $r \sim-0.29$ when shifted by 3 months and to a maximum of $r=-0.38$ when shifted by 8 months), and high and low $K_{G}$ 's are associated with the La Niña and El Niño phases (Figure 6). A temporal delay in the $K_{G}$ anomaly is not unreasonable, since ENSO-driven fire emission anomalies from drought-affected subcontinents are delayed by 2-5 months with respect to the ENSO index (Patra et al., 2005) (see also Figure S5 for the region of ENSO related emissions and duration of emissions). The increased emissions in carbon monoxide ( $\mathrm{CO})$ and nitrogen oxides $\left(\mathrm{NO}_{\mathrm{X}}\right)$ and volatile organic compounds (VOCs) affect the $\mathrm{OH}$ variability similarly, an instant reduction in $\mathrm{OH}$ by first-order reactions (Gaubert et al., 2017; Holmes et al., 2013; Nguyen et al., 2020; Stevenson et al., 2020). It has been proposed that elevated $\mathrm{OH}$ during La Niña is caused by increased convection and lightning in the tropics (Turner et al., 2018). However, no process-based chemistry-transport model re-produces this variability at interannual time scales, as has been derived from $\mathrm{CH}_{3} \mathrm{CCl}_{3}$ time series here. Low $\mathrm{OH}$ inferred during strong El Niño phases has been attributed to increased tropical cloud cover (shielding UV below clouds) and $\mathrm{OH}$-reduction by $\mathrm{CO}$ from global wildfires (Prinn et al., 2001, 2005). Recent analysis of CTM results confirms the (negative) link between ENSO and OH (Rowlinson et al., 2019; Zhao et al., 2020).

Figure 7 compares our results of the $\mathrm{K}_{\mathrm{G}}$ anomaly with results from various $\mathrm{CH}_{3} \mathrm{CCl}_{3}$ global analyses using box model approaches (Montzka et al., 2011; Naus et al., 2019; Rigby et al., 2017; Turner et al., 2017). We notice broad consistency in derived $K_{G}$ variations, specifically from studies using NOAA observations as the single data source (Montzka et al., 2011; Naus et al., 2019). Variations derived by two other studies deviate more from our results, specifically after 2010 (Rigby et al., 2017; Turner et al., 2017). As outlined in Naus et al. (2019), these deviations might be caused by the inability of box models to account for the changing global $\mathrm{CH}_{3} \mathrm{CCl}_{3}$ distribution. Likely also the choices of observational and model errors in these studies play an important role. Our new results for $K_{G}$ variability using a detailed 3D transport model exploit the information of the measurement networks to its full extent by accounting for transport variability and changes in the global $\mathrm{CH}_{3} \mathrm{CCl}_{3}$ distribution. Our results do not confirm the $\mathrm{OH}$ decline for the 2010-2015 period that was a potential conclusion from box model studies (Rigby et al., 2017; Turner et al., 2017).

When we compare our results to modeling efforts to quantify $\mathrm{OH}$ variability and trends using full CTMs in Figure 7b (Dalsøren et al., 2016; He et al., 2020; Stevenson et al., 2020), few similarities are found. Note that our derived long-term $K_{G}$ trend strongly depends on assumed $\mathrm{CH}_{3} \mathrm{CCl}_{3}$ emission declines after 2001, as shown by the results from the PP-OC-7.5 years scenarios. Changing the assumed emission decay time constant from 5 to 7.5 years leads to a $10 \% K_{G}$ increase in the 2002-2012 period (Figure $7 \mathrm{~b}$ ). Most models, except one that is based on a machine learning technique (Nicely et al., 2018), derive positive OH trends of roughly 3\% decade ${ }^{-1}$ during 1995-2017. Note that the no OH trend in Nicely et al. (2018), similar to our 
(a)

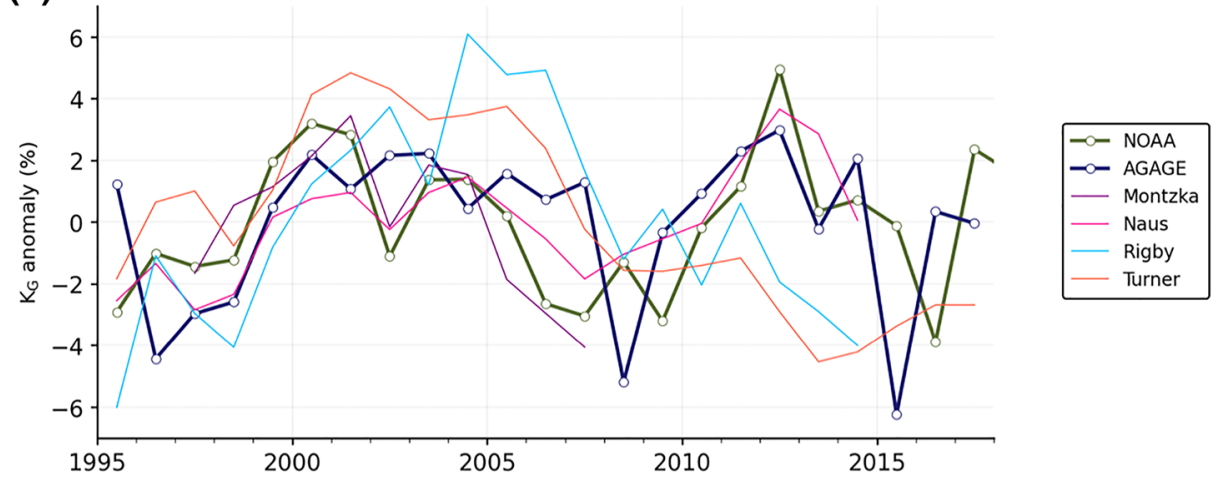

(b)

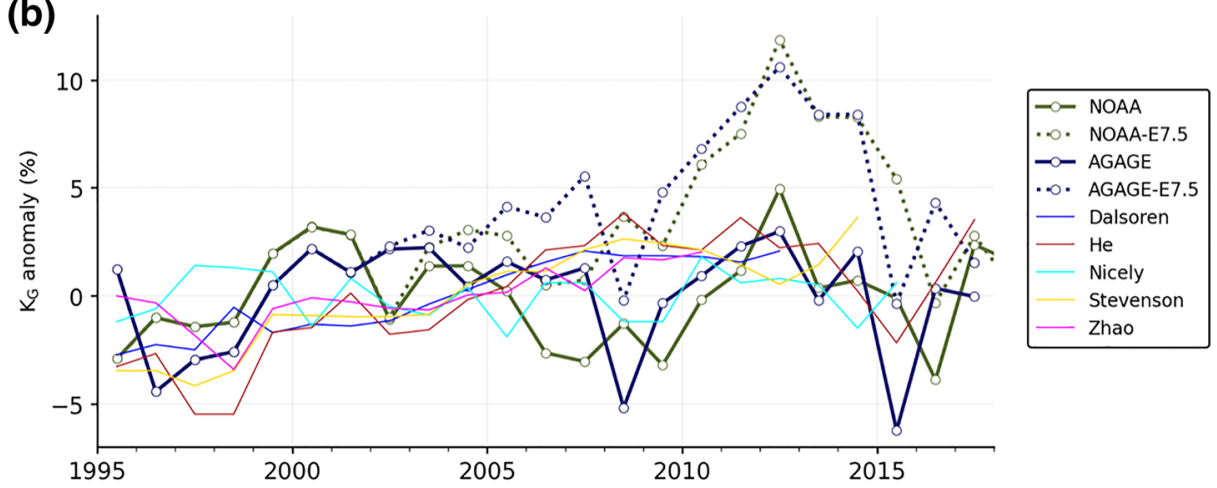

Figure 7. (a, upper panel) Comparisons between annual mean $K_{G}$ anomalies from this work and similar analyses using box models (Montzka et al., 2011; Turner et al., 2017; Rigby et al., 2017; Naus et al., 2019). (b, lower panel) Simulated OH variations using various CTMs (Dalsøren et al., 2016; He et al., 2020; Nicely et al., 2018]) or CTM ensembles (Stevenson et al., 2020; Zhao et al., 2020). $K_{g}$ variations in these model simulations are sometimes weighted by the $T$-dependent rate constant of the $\mathrm{CH}_{4}+\mathrm{OH}$ reaction, which has comparable $T$-dependence as the $\mathrm{CH}_{3} \mathrm{CCl}_{3}+\mathrm{OH}$ reaction. For comparison with calculated trends, also results from the scenario PP-OC-7.5 years are shown.

trends, are "chemical," since physical changes, which are dominated by temperature changes (Figure 5d), are accounted for by the CTMs. Chemical drivers of the $\mathrm{OH}$ long-term trend in modeling studies have been identified as the net effect of changing emissions and concentrations of near-term climate forcers, for example, decreases in $\mathrm{CO}$ and increases in $\mathrm{NO}_{\mathrm{x}}$ emissions (Stevenson et al., 2020). At the same time, however, key drivers of $\mathrm{OH}$ variabilities show the largest model diversity (Wild et al., 2020).

Differences between the networks do not lead to different conclusions concerning the small long-term trend in $K_{G}$. This trend, which is important for assessing the global methane budget, is critically sensitive to the $\mathrm{CH}_{3} \mathrm{CCl}_{3}$ emission history. We found that, even if we assume a slower decay in emissions, sustained positive $K_{G}$ anomalies after 2015 are not supported by recent observations. Reemission of $\mathrm{CH}_{3} \mathrm{CCl}_{3}$ previously dissolved into the oceans (Wennberg et al., 2004) might play a role, but this needs experimental confirmation and continued precise measurements of the global atmospheric $\mathrm{CH}_{3} \mathrm{CCl}_{3}$ decay rate in future years.

\section{Conclusions}

We have conducted simulations of $\mathrm{CH}_{3} \mathrm{CCl}_{3}$ during the period of 1985-2018 using the MIROC4-ACTM to estimate the variability in tropospheric $\mathrm{OH}$. Four different emission scenarios were used to test how sensitive the model simulations are to these scenarios, and how well the observed $\mathrm{CH}_{3} \mathrm{CCl}_{3}$ time series from 13 global sites from two different observational networks, namely, the AGAGE continuous on-site and NOAA flask sampling networks, are reproduced. The model simulations for the upper troposphere and stratosphere height regions are validated using balloon-borne cryo-sampling observations and a series of NASA 
aircraft experiments. We derived $K_{G}$ variability using independent observations from both the $\mathrm{CH}_{3} \mathrm{CCl}_{3}$ observation networks from 1998 to 2018. Our major conclusions are:

1. Model simulations show contrasting latitude-pressure distribution of $\mathrm{CH}_{3} \mathrm{CCl}_{3}$ in the period of high emissions and low emissions. The model simulations reproduce the concentration gradients in the upper troposphere and stratospheric altitudes observed during balloon and aircraft measurements well, suggesting that model transport and $\mathrm{CH}_{3} \mathrm{CCl}_{3}$ losses are well parameterized

2. The best overall agreement with the AGAGE measured time series is produce by the model simulations using the emission scenario that includes the oceanic sink (most significant in the period 1985-1995) and an emission decrease at a decay constant of 5 years during the period 2001-2019

3. Derived $K_{G}$ anomalies from the model-observation differences show consistent features using both AGAGE or NOAA data during most years. This internetwork consistency is obtained because the model-observation differences are found to be similar for all sites because the intersite gradients are simulated well by the model

4. The $K_{G}$ anomalies are separated into two components, physical (changes in temperature dependent reaction rate, stratosphere-troposphere exchange etc.) and chemical ( $\mathrm{OH}$ abundance change). The physical component caused only a small portion of the total interannual variability derived for $K_{G}(\sim 2.3 \%)$, but also showed systematic increase at a rate of $0.80 \%$ decade $^{-1}$ during the 1985-2018 period, predominantly because of secular increases in temperature

5. Interannual variations in chemical $K_{G}$ anomaly are related in part to ENSO variability, a decrease in $\mathrm{OH}$ during the El Niño phase and an increase in the La Niña phase is observed. Our detailed analysis suggests no significant trends in this $K_{G}$ anomaly (and therefore [OH]) during the 1996-2017 period

\section{Acknowledgments}

$\mathrm{CH}_{3} \mathrm{CCl}_{3}$ measurements continue to clarify more of the long-lasting uncertainties in $\mathrm{OH}$ variability and trends, thanks to the dedicated efforts by our colleagues contributing to the AGAGE and NOAA measurement programs. The Mace Head, Trinidad Head, Ragged Point, Cape Matatula, and Cape Grim AGAGE stations are supported by the National Aeronautics and Space Administration (NASA) (grants NNX16AC98G to MIT, and NNX16AC97G and NNX16AC96G to SIO). Support also comes from the UK Department for Business, Energy \& Industrial Strategy (BEIS) for Mace Head, the National Oceanic and Atmospheric Administration (NOAA) for Barbados, and the Commonwealth Scientific and Industrial Research Organization (CSIRO) and the Bureau of Meteorology (Australia) for Cape Grim. The balloon-borne measurements at Hyderabad were conducted by a collaborative project between the Max-Plank Institute of Aeronomy, Lindau and Indian Space Research Organisation (ISRO), Bangalore. Data archive: http://agage.mit.edu/ data. M. Krol received funding from the European Research Council (ERC) under the European Union's Horizon 2020 research and innovation program under grant agreement No 742798. S. Naus is supported by NWO (grant 824.15.002). This study is partly supported by the Arctic Challenge for Sustainability II grant (JPMXD1420318865) of the Ministry of Education, Science, Culture and Sports (MEXT), Japan; the Environment Research and Technology Development Fund (JPMEERF20182002) of the Environmental Restoration and Conservation Agency of Japan.

\section{Data Availability Statement}

NOAA flask data from their cooperative network are available for download from https://www.esrl.noaa. gov/gmd/hats/. AGAGE data are available from http://agage.mit.edu/data (incl. guidelines for use of AGAGE data) and ESS-DIVE website http://cdiac.ess-dive.lbl.gov/ndps/alegage.html.

\section{References}

Arnold, T., Mühle, J., Salameh, P. K., Harth, C. M., Ivy, D. J., \& Weiss, R. F. (2012). Automated measurement of nitrogen trifluoride in ambient air. Analytical Chemistry, 84(11), 4798-4804. https://doi.org/10.1021/ac300373e

Bousquet, P., Hauglustaine, D. A., Peylin, P., Carouge, C., \& Ciais, P. (2005). Two decades of OH variability as inferred by an inversion of atmospheric transport and chemistry of methyl chloroform. Atmospheric Chemistry and Physics, 5(10), 2635-2656. https://doi. org/10.5194/acp-5-2635-2005

Brenninkmeijer, C. A. M., Manning, M. R., Lowe, D. C., Wallace, G., Sparks, R. J., \& Volz-Thomas, A. (1992). Interhemispheric asymmetry in $\mathrm{OH}$ abundance inferred from measurements of atmospheric 14CO. Nature, 356(6364), 50-52. https://doi.org/10.1038/356050a0

Burkholder, J. B., Sander, S. P., Abbatt, J., Barker, J. R., Huie, R. E., Kolb, C. E., et al. (2015). Chemical kinetics and photochemical data for use in atmospheric studies: Evaluation no. 18. Pasadena, CA: Jet Propulsion Laboratory, National Aeronautics and Space Administration. http://hdl.handle.net/2014/45510

Butler, J. H., Elkins, J. W., Thompson, T. M., Hall, B. D., Swanson, T. H., \& Koropalov, V. (1991). Oceanic consumption of CH $\mathrm{CCl}_{3}$ : Implications for tropospheric OH. Journal of Geophysical Research, 96(D12), 22347. https://doi.org/10.1029/91JD02126

Crutzen, P. J., \& Zimmermann, P. H. (1991). The changing photochemistry of the troposphere. Tellus A: Dynamic Meteorology and Oceanography, 43(4), 136-151. https://doi.org/10.3402/tellusa.v43i4.11943

Dalsøren, S. B., Myhre, C. L., Myhre, G., Gomez-Pelaez, A. J., Søvde, O. A., Isaksen, I. S. A., et al. (2016). Atmospheric methane evolution the last 40 years. Atmospheric Chemistry and Physics, 16(5), 3099-3126. https://doi.org/10.5194/acp-16-3099-2016

Elkins, J. W., Fahey, D. W., Gilligan, J. M., Dutton, G. S., Baring, T. J., Volk, C. M., et al. (1996). Airborne gas chromatograph for in situ measurements of long-lived species in the upper troposphere and lower stratosphere. Geophysical Research Letters, 23(4), 347-350. https://doi.org/10.1029/96GL00244

Fabian, P., Borchers, R., Leifer, R., Subbaraya, B. H., Lal, S., \& Boy, M. (1996). Global stratospheric distribution of halocarbons. Atmospheric Environment, 30(10-11), 1787-1796. https://doi.org/10.1016/1352-2310(95)00387-8

Francey, R. J., Frederiksen, J. S., Paul Steele, L., \& Langenfelds, R. L. (2019). Variability in a four-network composite of atmospheric CO differences between three primary baseline sites. Atmospheric Chemistry and Physics, 19(23), 14741-14754. https://doi.org/10.5194/ acp-19-14741-2019

Gaubert, B., Worden, H. M., Arellano, A. F. J., Emmons, L. K., Tilmes, S., Barré, J., et al. (2017). Chemical feedback from decreasing carbon monoxide emissions. Geophysical Research Letters, 44(19), 9985-9995. https://doi.org/10.1002/2017GL074987

He, J., Naik, V., Horowitz, L. W., Dlugokencky, E., \& Thoning, K. (2020). Investigation of the global methane budget over 1980\&\#8211;2017 using GFDL-AM4.1. Atmospheric Chemistry and Physics, 20(2), 805-827. https://doi.org/10.5194/acp-20-805-2020

Holmes, C. D., Prather, M. J., Søvde, O. A., \& Myhre, G. (2013). Future methane, hydroxyl, and their uncertainties: Key climate and emission parameters for future predictions. Atmospheric Chemistry and Physics, 13(1), 285-302. https://doi.org/10.5194/acp-13-285-2013 
Kobayashi, S., Ota, Y., Harada, Y., Ebita, A., Moriya, M., Onoda, H., et al. (2015). The JRA-55 reanalysis: General specifications and basic characteristics. Journal of the Meteorological Society of Japan, 93(1), 5-48. https://doi.org/10.2151/jmsj.2015-001

Krol, M. C., \& Lelieveld, J. (2003). Can the variability in tropospheric OH be deduced from measurements of 1,1,1-trichloroethane (methyl chloroform)? Journal of Geophysical Research, 108(3), 4125. https://doi.org/10.1029/2002jd002423

Krol, M. C., Meirink, J. F., Bergamaschi, P., Mak, J. E., Lowe, D., Jöckel, P., et al. (2008). What can 14CO measurements tell us about OH? Atmospheric Chemistry and Physics, 8(16), 5033-5044. https://doi.org/10.5194/acp-8-5033-2008

Lal, S., Borchers, R., Fabian, P., Patra, P. K., \& Subbaraya, B. H. (1994). Vertical distribution of methyl bromide over Hyderabad, India. Tellus B: Chemical and Physical Meteorology, 46(5), 373-377. https://doi.org/10.1034/j.1600-0889.1994.t01-3-00003.x

Lelieveld, J., Bourtsoukidis, E., Brühl, C., Fischer, H., Fuchs, H., Harder, H., et al. (2018). The South Asian monsoon—pollution pump and purifier. Science, 361(6399), 270-273. https://doi.org/10.1126/science.aar2501

Lelieveld, J., Peters, W., Dentener, F. J., \& Krol, M. C. (2002). Stability of tropospheric hydroxyl chemistry. Journal of Geophysical Research, 107(D23), ACH17-1-ACH17-11. https://doi.org/10.1029/2002JD002272

Levy, H. (1971). Normal atmosphere: Large radical and formaldehyde concentrations predicted. Science, 173(3992), 141-143. https://doi. org/10.1126/science.173.3992.141

Lovelock, J. E. (1977). Methyl chloroform in the troposphere as an indicator of OH radical abundance. Nature, 267(5606), 32. https://doi. org/10.1038/267032a0

Makide, Y., \& Rowland, F. S. (1981). Tropospheric concentrations of methylchloroform, $\mathrm{CH}_{3} \mathrm{CCl}_{3}$, in January 1978 and estimates of the atmospheric residence times for hydrohalocarbons. Proceedings of the National Academy of Sciences of the United States of America, 78(10), 5933-5937. https://doi.org/10.1073/pnas.78.10.5933

McCulloch, A., \& Midgley, P. (2001). The history of methyl chloroform emissions: 1951-2000. Atmospheric Environment, 35(31), 53115319. https://doi.org/10.1016/S1352-2310(01)00306-5

McNorton, J., Chipperfield, M. P., Gloor, M., Wilson, C., Feng, W., Hayman, G. D., et al. (2016). Role of OH variability in the stalling of the global atmospheric $\mathrm{CH}_{4}$ growth rate from 1999 to 2006. Atmospheric Chemistry and Physics, 16(12), 7943-7956. https://doi.org/10.5194/ acp-16-7943-2016

Miller, B. R., Weiss, R. F., Salameh, P. K., Tanhua, T., Greally, B. R., Mühle, J., \& Simmonds, P. G. (2008). Medusa: A sample preconcentration and GC/MS detector system for in situ measurements of atmospheric trace halocarbons, hydrocarbons, and sulfur compounds Analytical Chemistry, 80(5), 1536-1545. https://doi.org/10.1021/ac702084k

Montzka, S. A. (2000). New observational constraints for atmospheric hydroxyl on global and hemispheric scales. Science, 288(5465), 500-503. https://doi.org/10.1126/science.288.5465.500

Montzka, S. A., Krol, M., Dlugokencky, E., Hall, B., Jöckel, P., \& Lelieveld, J. (2011). Small interannual variability of global atmospheric hydroxyl. Science, 331(6013), 67-69. https://doi.org/10.1126/science.1197640

Murray, L. T., Mickley, L. J., Kaplan, J. O., Sofen, E. D., Pfeiffer, M., \& Alexander, B. (2014). Factors controlling variability in the oxidative capacity of the troposphere since the Last Glacial Maximum. Atmospheric Chemistry and Physics, 14(7), 3589-3622. https://doi. org/10.5194/acp-14-3589-2014

Naik, V., Voulgarakis, A., Fiore, A. M., Horowitz, L. W., Lamarque, J. F., Lin, M., et al. (2013). Preindustrial to present-day changes in tropospheric hydroxyl radical and methane lifetime from the Atmospheric Chemistry and Climate Model Intercomparison Project (ACCMIP). Atmospheric Chemistry and Physics, 13(10), 5277-5298. https://doi.org/10.5194/acp-13-5277-2013

Naus, S., Montzka, S. A., Pandey, S., Basu, S., Dlugokencky, E. J., \& Krol, M. (2019). Constraints and biases in a tropospheric two-box model of OH. Atmospheric Chemistry and Physics, 19(1), 407-424. https://doi.org/10.5194/acp-19-407-2019

Naus, S., Montzka, S. A., Patra, P. K., \& Krol, M. C. (2020). A 3D-model inversion of methyl chloroform to constrain the atmospheric oxidative capacity. Atmospheric Chemistry and Physics Discussions. https://doi.org/10.5194/acp-2020-624

Nguyen, N. H., Turner, A. J., Yin, Y., Prather, M. J., \& Frankenberg, C. (2020). Effects of chemical feedbacks on decadal methane emissions estimates. Geophysical Research Letters, 47(3). https://doi.org/10.1029/2019gl085706

Nicely, J. M., Canty, T. P., Manyin, M., Oman, L. D., Salawitch, R. J., Steenrod, S. D., et al. (2018). Changes in global tropospheric OH expected as a result of climate change over the last several decades. Journal of Geophysical Research: Atmospheres, 123(18), 10774-10795. https://doi.org/10.1029/2018JD028388

Nicely, J. M., Duncan, B. N., Hanisco, T. F., Wolfe, G. M., Salawitch, R. J., Deushi, M., et al. (2020). A machine learning examination of hydroxyl radical differences among model simulations for CCMI-1. Atmospheric Chemistry and Physics, 20(3), 1341-1361. https://doi. org/10.5194/acp-20-1341-2020

Patra, P. K., Houweling, S., Krol, M., Bousquet, P., Belikov, D., Bergmann, D., et al. (2011). TransCom model simulations of $\mathrm{CH}_{4}$ and related species: Linking transport, surface flux and chemical loss with $\mathrm{CH}_{4}$ variability in the troposphere and lower stratosphere. Atmospheric Chemistry and Physics, 11(24), 12813-12837. https://doi.org/10.5194/acp-11-12813-2011

Patra, P. K., Ishizawa, M., Maksyutov, S., Nakazawa, T., \& Inoue, G. (2005). Role of biomass burning and climate anomalies for land-atmosphere carbon fluxes based on inverse modeling of atmospheric $\mathrm{CO}_{2}$. Global Biogeochemical Cycles, 19(3), GB3005. https://doi org/10.1029/2004GB002258

Patra, P. K., Krol, M. C., Montzka, S. A., Arnold, T., Atlas, E. L., Lintner, B. R., et al. (2014). Observational evidence for interhemispheric hydroxyl-radical parity. Nature, 513(7517), 219-223. https://doi.org/10.1038/nature13721

Patra, P. K., Takigawa, M., Watanabe, S., Chandra, N., Ishijima, K., \& Yamashita, Y. (2018). Improved chemical tracer simulation by MIROC4.0-based atmospheric chemistry-transport model (MIROC4-ACTM). Scientific Online Letters on the Atmosphere, 14, 91-96. https:// doi.org/10.2151/sola.2018-016

Prather, M., \& Spivakovsky, C. M. (1990). Tropospheric OH and the lifetimes of hydrochlorofluorocarbons. Journal of Geophysical Research, 95(D11), 18723. https://doi.org/10.1029/JD095iD11p18723

Prinn, R. G., Cunnold, D., Simmonds, P., Alyea, F., Boldi, R., Crawford, A., et al. (1992). Global average concentration and trend for hydroxyl radicals deduced from ALE/GAGE trichloroethane (methyl chloroform) data for 1978-1990. Journal of Geophysical Research, 97(D2), 2445. https://doi.org/10.1029/91JD02755

Prinn, R. G., Huang, J., Weiss, R. F., Cunnold, D. M., Fraser, P. J., Simmonds, P. G., et al. (2001). Evidence for substantial variations of atmospheric hydroxyl radicals in the past two decades. Science, 292(5523), 1882-1888. https://doi.org/10.1126/science.1058673

Prinn, R. G., Huang, J., Weiss, R. F., Cunnold, D. M., Fraser, P. J., Simmonds, P. G., et al. (2005). Evidence for variability of atmospheric hydroxyl radicals over the past quarter century. Geophysical Research Letters, 32(7), L07809. https://doi.org/10.1029/2004GL022228

Prinn, R. G., Weiss, R. F., Arduini, J., Arnold, T., DeWitt, H. L., Fraser, P. J., et al. (2018). History of chemically and radiatively important atmospheric gases from the Advanced Global Atmospheric Gases Experiment (AGAGE). Earth System Science Data, 10(2), 985-1018. https://doi.org/10.5194/essd-10-985-2018 
Prinn, R. G., Weiss, R. F., Fraser, P. J., Simmonds, P. G., Cunnold, D. M., Alyea, F. N., et al. (2000). A history of chemically and radiatively important gases in air deduced from ALE/GAGE/AGAGE. Journal of Geophysical Research, 105(D14), 17751-17792. https://doi. org/10.1029/2000JD900141

Rigby, M., Montzka, S. A., Prinn, R. G., White, J. W. C., Young, D., O'Doherty, S., et al. (2017). Role of atmospheric oxidation in recent methane growth. Proceedings of the National Academy of Sciences of the United States of America, 114(21), 5373-5377. https://doi. org/10.1073/pnas.1616426114

Romashkin, P. A., Hurst, D. F., Elkins, J. W., Dutton, G. S., Fahey, D. W., Dunn, R. E., et al. (2001). In situ measurements of long-lived trace gases in the lower stratosphere by gas chromatography. Journal of Atmospheric and Oceanic Technology, 18(7), 1195-1204. https://doi.or g/10.1175/1520-0426(2001)018<1195:ISMOLL >2.0.CO;2

Rowlinson, M. J., Rap, A., Arnold, S. R., Pope, R. J., Chipperfield, M. P., McNorton, J., et al. (2019). Impact of El Niño-Southern Oscillation on the interannual variability of methane and tropospheric ozone. Atmospheric Chemistry and Physics, 19(13), 8669-8686. https://doi. org/10.5194/acp-19-8669-2019

Seinfeld, J. H., \& Pandis, S. N. (2006). Atmospheric chemistry and physics: From air pollution to climate change. New York, NY: John Wiley \& Sons. ISBN: 978-1-118-94740-1.

Singh, H. B., Kanakidou, M., Crutzen, P. J., \& Jacob, D. J. (1995). High concentrations and photochemical fate of oxygenated hydrocarbons in the global troposphere. Nature, 378(6552), 50-54. https://doi.org/10.1038/378050a0

Spivakovsky, C. M., Logan, J. A., Montzka, S. A., Balkanski, Y. J., Foreman-Fowler, M., Jones, D. B. A., et al. (2000). Three-dimensional climatological distribution of tropospheric OH: Update and evaluation. Journal of Geophysical Research, 105(D7), 8931-8980. https:// doi.org/10.1029/1999JD901006

Stevenson, D. S., Zhao, A., Naik, V., O'Connor, F. M., Tilmes, S., Zeng, G., et al. (2020). Trends in global tropospheric hydroxyl radical and methane lifetime since 1850 from AerChemMIP. Atmospheric Chemistry and Physics, 20(21), 12905-12920. https://doi.org/10.5194/ acp-20-12905-2020

Takahashi, T., Sutherland, S. C., Wanninkhof, R., Sweeney, C., Feely, R. A., Chipman, D. W., et al. (2009). Climatological mean and decadal change in surface ocean $\mathrm{pCO}_{2}$, and net sea-air $\mathrm{CO}_{2}$ flux over the global oceans. Deep Sea Research Part II: Topical Studies in Oceanography, 56(8-10), 554-577. https://doi.org/10.1016/j.dsr2.2008.12.009

Takigawa, M., Takahashi, M., \& Akiyoshi, H. (1999). Simulation of ozone and other chemical species using a Center for Climate System Research/National Institute for Environmental Studies atmospheric GCM with coupled stratospheric chemistry. Journal of Geophysical Research, 104(D11), 14003-14018. https://doi.org/10.1029/1998JD100105

Turner, A. J., Frankenberg, C., Wennberg, P. O., \& Jacob, D. J. (2017). Ambiguity in the causes for decadal trends in atmospheric methane and hydroxyl. Proceedings of the National Academy of Sciences of the United States of America, 114(21), 5367-5372. https://doi. org/10.1073/pnas.1616020114

Turner, A. J., Fung, I., Naik, V., Horowitz, L. W., \& Cohen, R. C. (2018). Modulation of hydroxyl variability by ENSO in the absence of external forcing. Proceedings of the National Academy of Sciences of the United States of America, 115(36), 8931-8936. https://doi.org/10.1073/ pnas. 1807532115

Voulgarakis, A., Naik, V., Lamarque, J.-F., Shindell, D. T., Young, P. J., Prather, M. J., et al. (2013). Analysis of present day and future $\mathrm{OH}$ and methane lifetime in the ACCMIP simulations. Atmospheric Chemistry and Physics, 13(5), 2563-2587. https://doi.org/10.5194/ acp-13-2563-2013

Watanabe, S., Kawatani, Y., Tomikawa, Y., Miyazaki, K., Takahashi, M., \& Sato, K. (2008). General aspects of a T213L256 middle atmosphere general circulation model. Journal of Geophysical Research, 113(12), D12110. https://doi.org/10.1029/2008JD010026

Wells, K. C., Millet, D. B., Payne, V. H., Deventer, M. J., Bates, K. H., de Gouw, J. A., et al. (2020). Satellite isoprene retrievals constrain emissions and atmospheric oxidation. Nature, 585(7824), 225-233. https://doi.org/10.1038/s41586-020-2664-3

Wennberg, P. O., Peacock, S., Randerson, J. T., \& Bleck, R. (2004). Recent changes in the air-sea gas exchange of methyl chloroform. Geophysical Research Letters, 31(16), L16112. https://doi.org/10.1029/2004GL020476

Wild, O., Voulgarakis, A., O\&apos, Connor, F., Lamarque, J.-F., Ryan, E. M., \& Lee, L. (2020). Global sensitivity analysis of chemistry-climate model budgets of tropospheric ozone and $\mathrm{OH}$ : Exploring model diversity. Atmospheric Chemistry and Physics, 20(7), 4047-4058. https://doi.org/10.5194/acp-20-4047-2020

Wolfe, G. M., Nicely, J. M., Clair, St. J. M., Hanisco, T. F., Liao, J., Oman, L. D., et al. (2019). Mapping hydroxyl variability throughout the global remote troposphere via synthesis of airborne and satellite formaldehyde observations. Proceedings of the National Academy of Sciences of the United States of America, 116(23), 11171-11180. https://doi.org/10.1073/pnas.1821661116

Wolter, K., \& Timlin, M. S. (2011). El Niño/Southern Oscillation behaviour since 1871 as diagnosed in an extended multivariate ENSO index (MEI.ext). International Journal of Climatology, 31(7), 1074-1087. https://doi.org/10.1002/joc.2336

Zhao, Y., Saunois, M., Bousquet, P., Lin, X., Berchet, A., Hegglin, M. I., et al. (2019). Inter-model comparison of global hydroxyl radical $(\mathrm{OH})$ distributions and their impact on atmospheric methane over the 2000-2016 period. Atmospheric Chemistry and Physics, 19(21), 13701-13723. https://doi.org/10.5194/acp-19-13701-2019

Zhao, Y., Saunois, M., Bousquet, P., Lin, X., Berchet, A., Hegglin, M. I., et al. (2020). Influences of hydroxyl radicals (OH) on top-down estimates of the global and regional methane budgets. Atmospheric Chemistry and Physics, 20(15), 9525-9546. https://doi.org/10.5194/ acp-20-9525-2020 